DIW BERLIN

Discussion

Papers
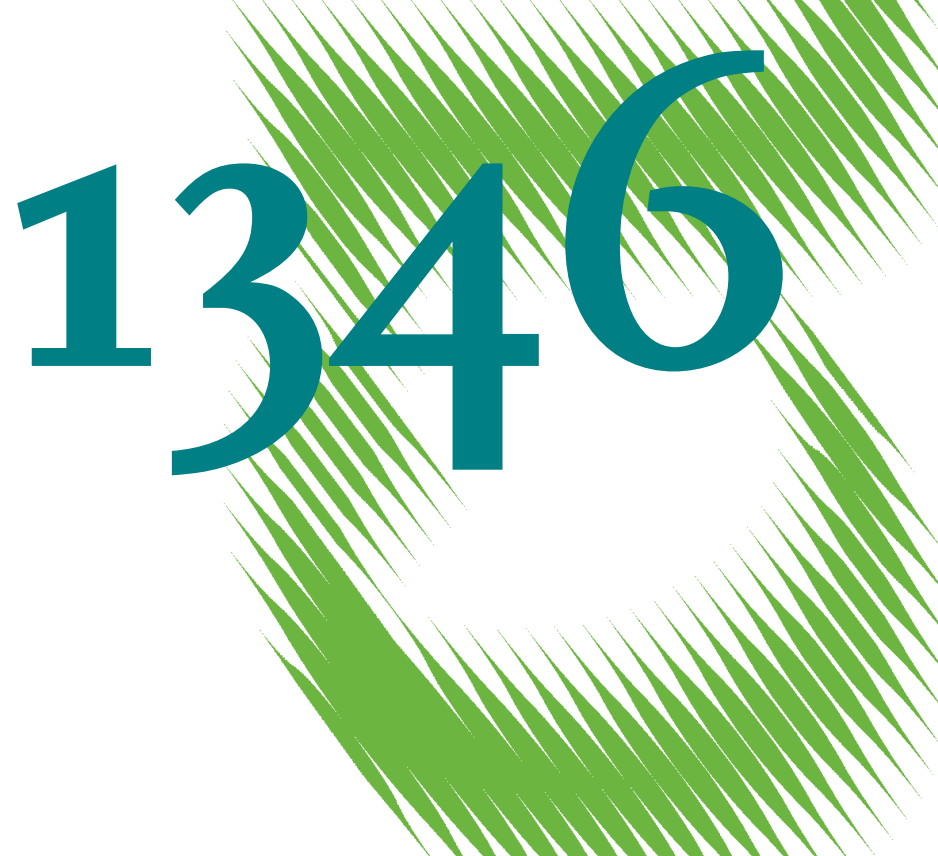

Granularity in Banking and Growth

Does Financial Openness Matter? 
Opinions expressed in this paper are those of the author(s) and do not necessarily reflect views of the institute.

IMPRESSUM

(C) DIW Berlin, 2013

DIW Berlin

German Institute for Economic Research

Mohrenstr. 58

10117 Berlin

Tel. $+49(30) 89789-0$

Fax +49 (30) $89789-200$

http://www.diw.de

ISSN print edition $1433-0210$

ISSN electronic edition 1619-4535

Papers can be downloaded free of charge from the DIW Berlin website:

http://www.diw.de/discussionpapers

Discussion Papers of DIW Berlin are indexed in RePEc and SSRN:

http://ideas.repec.org/s/diw/diwwpp.html

http://www.ssrn.com/link/DIW-Berlin-German-Inst-Econ-Res.html 


\title{
Granularity in Banking and Growth: Does Financial Openness Matter?
}

\author{
Franziska Bremus \\ (DIW Berlin) \\ Claudia M. Buch ${ }^{1}$ \\ (University of Magdeburg, Halle Institute for Economic Research, and CESifo)
}

August 2013

\begin{abstract}
We explore the impact of large banks and of financial openness for aggregate growth. Large banks matter because of granular effects: if markets are very concentrated in terms of the size distribution of banks, idiosyncratic shocks at the bank-level do not cancel out in the aggregate but can affect macroeconomic outcomes. Financial openness may affect GDP growth in and of itself, and it may also influence concentration in banking and thus the impact of bank-specific shocks for the aggregate economy. To test these relationships, we use different measures of de jure and de facto financial openness in a linked micromacro panel dataset. Our research has three main findings: First, bank-level shocks significantly impact on GDP. Second, financial openness lowers GDP growth. Third, granular effects tend to be stronger in financially closed economies.
\end{abstract}

Key words: $\quad$ Bank market structure, financial openness, granular effects, growth

JEL classification: $\quad$ G21, E32

1 Corresponding author: Claudia Buch, Halle Institute for Economic Research (IWH), Kleine Maerkerstraße 8, 06108 Halle, Germany, Phone: +49 3457753 700. E-mail: Claudia.Buch@iwh-halle.de.

This paper was written in the context of the Priority Programme SPP1578 "Financial Market Imperfections and Macroeconomic Performance" of the German National Science Foundation (DFG). Funding from the DFG is gratefully acknowledged. We thank Jörg Breitung, Sandra Eickmeier, Neeltje van Horen, and participants of seminars at the University of Mannheim, the Central Bank of Luxembourg, the Frankfurt School of Business and Finance, and at the London Business School for very helpful comments on an earlier version. All errors are solely our own responsibility. 


\section{Motivation}

This paper contributes to an improved understanding of links between the real and financial sector. We focus on granular effects in banking and how these effects are influenced by financial openness. Granular effects arise if markets are very concentrated. If a few large banks coexist with many small banks, idiosyncratic shocks to individual banks do not have to cancel out in the aggregate but can affect macroeconomic growth. The importance of granular effects has been shown for aggregate fluctuations in the US (Gabaix 2011), for international trade (Di Giovanni and Levchenko 2009), and for domestic banking markets (Amiti and Weinstein 2013, Bremus et al. 2013). Thus, besides issues of connectedness or moral hazard, large banks can affect aggregate growth simply by being large.

Consequently, many current policy initiatives aim at restricting bank size by imposing bank levies with progressive tax rates or by imposing higher capital buffers on systemically important banks. At the same time, banking markets are becoming increasingly segmented, and many policy initiatives - explicitly or implicitly - aim at reducing financial openness. ${ }^{2}$ Yet, we know little, both empirically and theoretically, on the interaction between size effects in banking, financial openness, and macroeconomic outcomes. Closing this gap is the purpose of this paper.

We use a linked micro-macro panel dataset to analyze how granular effects in banking and financial openness affect aggregate output. Our bank-level data are obtained from Bankscope. In line with Gabaix (2011), we measure granular effects - the "banking granular residual” - as the weighted sum of bank-specific shocks to total assets where the weights reflect banks' market shares. We account for the fact that the impact of banklevel shocks may differ for countries with different degrees of financial openness. Our research has three main findings: (i) idiosyncratic bank-level shocks are positively related

\footnotetext{
${ }^{2}$ Rose and Wieladek (2011) find that, after nationalization, foreign banks reduce the share of loans going to the UK, which can be interpreted as evidence for financial protectionism. In Europe, state support for banks was often conditioned on the requirements to close foreign affiliates. Also, banks' sovereign debt portfolios in Europe have exhibited an increasing degree of "home bias" since the outbreak of the sovereign debt crisis (Pockrandt and Radde 2012).
} 
to GDP growth, (ii) a high degree of financial openness lowers growth, and (iii) granular effects from the banking sector tend to be more pronounced in economies which have a low degree of financial openness.

Previous literature has shown that the link between financial openness and aggregate outcomes is non-linear (Kose et al. 2011): At low levels of institutional or financial development, financial openness may harm growth. At high levels of institutional development, financial openness increases growth. Klein and Olivei (2008) show that capital account openness increases financial depth and thereby economic growth. The link between financial openness and growth volatility depends on the size of domestic credit markets in a non-linear way as well (Kose et al. 2003, 2009).

We complement this research by analyzing inter-linkages between granular effects in banking and financial openness. Granular effects reflect distortions in the domestic banking sector in the form of a dominance of large banks. In financially closed economies, firms have few substitutes to bank credit. They cannot easily switch to nonbank or foreign suppliers of finance. Hence, the effects of idiosyncratic shocks hitting large banks may be particularly severe. The impact of large banks may become less important for domestic macroeconomic developments if a country is financially more open.

Granularity in banking has, so far, been analyzed in closed-economy settings. Empirically, size distributions in banking resemble a fat-tailed power law distribution which is necessary to generate granular effects (Bremus et al. 2013). Moreover, granularity in banking matters for short-run output fluctuations in Eastern Europe (Buch and Neugebauer 2011), and shocks to large banks affect the probability of default of smaller banks in Germany (Blank et al. 2009). Using credit register data to isolate loan supply shocks, Amiti and Weinstein (2013) show that credit supply shocks matter for aggregate loan supply and investment in Japan.

Analyzing granular effects in open economies is a straight-forward extension of previous work. In the international trade literature, Di Giovanni and Levchenko (2009) extend the original idea by Gabaix (2011) and show the implications of greater trade openness for macroeconomic volatility. They use a Melitz-type model of heterogeneous firms in which 
firm size distributions that follow a power law evolve (Melitz 2003). The model can be used to show that macroeconomic volatility is a function of idiosyncratic shocks and of market structure, measured through an industry's Herfindahl index. Following the liberalization of external trade, large firms emerge endogenously because the most productive firms get bigger and the least productive, smallest firms exit. This mechanism can explain the positive correlation between trade openness and output volatility found in many empirical studies (Di Giovanni and Levchenko 2009).

Comparable models in international banking have been developed more recently. Financial openness may affect market structure in banking markets. De Blas and Russ (2010, 2013) model financial openness through FDI of banks and through cross-border lending in the presence of heterogeneous banks. These two forms of financial openness may have different effects on the banking sector's Herfindahl index. Cross-border lending puts competitive pressure on domestic banks, market shares may become more similar, and the degree of concentration falls (Bremus 2013). If competition gets more intense, banks absorb a larger part of idiosyncratic shocks by adjusting markups instead of lending rates. As a result, the pass-through of bank-level shocks to the real economy gets weaker. This mitigates granular effects. Bank FDI may increase or decrease concentration. If the most efficient banks from abroad merge with the most efficient domestic banks and if the smallest banks drop out of the market, the big banks would get bigger. This would magnify the link between bank-level shock and macroeconomic outcomes via increased concentration. But bank FDI may also decrease concentration if banks’ market shares get more similar as presented by Bremus (2013). Hence, different channels of financial openness can have different implications for the strength of granular effects. It ultimately remains an empirical question whether financial openness affects the strength of granular effects in banking.

In order to analyze these linkages, Part 2 introduces the data and explains how we measure granularity, growth, and financial openness. Part 3 has the empirical model and results, and Part 4 concludes. 


\section{Data and Measurement of Granular Effects}

In this paper, we analyze whether idiosyncratic shocks affecting large banks influence the aggregate economy and whether this link depends on the degree of financial openness. Below, we describe how we measure idiosyncratic and macroeconomic growth as well as financial openness. Details on the measurement and the data sources are given in the Data Appendix.

\subsection{Granularity in Banking}

We apply the concept of granularity to the banking sector. Granularity effects arise if the distribution of firm sizes is highly dispersed. If many small firms coexist with a few very large ones such that concentration is high, idiosyncratic shocks to large firms can be felt in the aggregate (Gabaix 2011). Hence, market structure matters for macroeconomic outcomes.

Technically speaking, the necessary condition for granularity to emerge is that firm sizes are power-law distributed. Under a normal distribution, idiosyncratic shocks cancel out across a large number of firms in the aggregate because the Central Limit Theorem holds. Under a fat-tailed power law distribution, however, the Central Limit Theorem breaks down. As a consequence, firm-specific fluctuations can have aggregate effects.

Gabaix’s original application of granularity links variation in GDP growth to idiosyncratic shocks hitting large US manufacturing firms. He shows that GDP growth is proportional to the growth rate of total factor productivity (TFP), which can be expressed as the sum over firms' market shares times idiosyncratic TFP-shocks $\left(d \pi_{i t}\right)$. GDP growth can thus be written as

$$
\frac{d G D P}{G D P}=\lambda\left[\sum_{i=1}^{N}\left(\frac{S_{i t}}{G D P_{t}}\right) \cdot d \pi_{i t}\right],
$$

where $S_{i t}$ are firm $i$ 's sales in period $t$, and $\lambda$ is a factor which determines proportionality. Gabaix (2011) labels the sum across the weighted idiosyncratic shock terms the "granular residual”. He computes the granular residual, $\Gamma_{t}$, as the weighted sum of idiosyncratic firm-level productivity shocks which is given by 


$$
\Gamma_{t}=\sum_{i=1}^{N}\left(\frac{S_{i t-1}}{S_{t-1}}\right) \cdot\left(g_{i t}-\bar{g}_{t}\right),
$$

where $g_{i t}$ is firm i's productivity growth while $\bar{g}_{t}$ is the average productivity growth in an economy at time $t$, and the weights are firm i's sales market share.

We apply the concept of granularity to the banking sector. Our source for bank-level data is Bankscope, a commercial database provided by Bureau van Dijck. Bankscope provides income statements and balance sheets for banks worldwide. This restricts the time frame for our analysis. While macroeconomic data are available for a much longer time period, reliable micro-level bank data start only in the mid-1990s. We compute the banking granular residual (BGR) for a set of 80 countries as the weighted sum of bank-level shocks to assets or credit in each country and year, the weights being banks' asset (credit) market shares.

A number of screens are imposed on the banking data in order to eliminate errors due to misreporting. We exclude the bottom $1 \%$ of the observations for total assets, and we drop observations where the credit-to-assets or the equity-to-assets ratio is larger than one. We drop banks with negative assets, credits, or equity. In order to eliminate large (absolute) growth rates that might be due to bank mergers, we winsorize growth rates at the top or bottom percentile, i.e. we replace them with the respective percentiles. In terms of specializations of banks, we keep bank holding companies, commercial banks, cooperative banks, and savings banks.

Our measure of granular shocks closely follows Gabaix’s (2011) original proposal to calculate the growth rate of a firm's sales and subtracting the average growth rate across all firms for each year. This difference is a simple proxy of firms' idiosyncratic growth shocks. Because we are using data for banks from many countries, we slightly modify this method by subtracting, from each bank's growth rate of assets (or loans), the mean growth rates across all banks (except bank $j$ ) in each country and year. The reason for taking the average across all banks except bank $j$ is that, for some countries, a rather small number of bank observations is available only. If we subtract the average across all banks (including bank $j$ ) from bank $j$ 's asset (credit) growth, we may eliminate most of 
bank j's idiosyncratic variation. This holds in particular if there is a small number of bank observations and if bank $j$ is large.

Finding a clear analogy between the sales of non-financial firms (used by Gabaix) and the turnover or the sales of banks is not straightforward. We instead compute both banks' asset and credit growth shocks for three reasons.

First, differences in accounting systems across countries may impair the comparability of balance sheet and profit and loss items across countries and over time. Therefore, we opt for relatively simple and straightforward balance sheet items - total assets and loans - to measure the activities of banks.

Second, differences in productivity or efficiency of banks translate into differences in lending or bank size, which we can proxy through a bank's loans or assets (De Blas and Russ 2013). Direct measures of bank productivity or efficiency would be much more dependent on data quality and comparability across countries.

Three, the volume of credit issued by banks is the most direct measure of banks' link to the real economy. The bank lending channel literature discusses how monetary policy and thus macro shocks affect the real economy through changes in bank behaviour. Using linked bank-firm data, Amiti and Weinstein (2013) find that idiosyncratic shocks at the bank-level can have a significant impact on aggregate loan supply and investment, and hence on the real economy. Bremus et al. (2013) show how shocks to bank efficiency translate to macroeconomic output in a simple general equilibrium model which features banks of different efficiency and of different size.

Having computed asset (credit) growth shocks for each individual bank, we calculate a measure of granular effects in the banking sector for each country and year. The banking granular residual (BGR) is obtained by multiplying the idiosyncratic shocks with the market share of each bank, and summing across all banks per country and year:

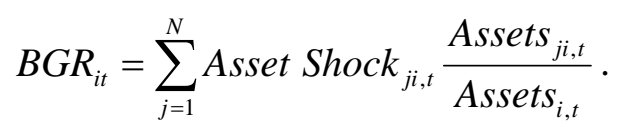

Assets $_{j i, t}$ denotes total assets of bank $j$ in country $i$ at time $t$ while Assets ${ }_{i, t}$ are aggregate bank assets in country $i$, year $t$. 
Figure 1 illustrates the evolution of the banking granular residual over time. Idiosyncratic bank-level shocks based on loans and based on assets are in the same order of magnitude and evolve similarly over time. The two alternative measures of the BGR have similar moments with a mean of about zero and a standard deviation of roughly 0.1 (Table 1 ). Finding a zero mean for the panel dataset does not mean that idiosyncratic shocks average out at each point in time. Figure 1 rather shows that average fluctuations in banklevel asset and credit growth shocks rather vary between -0.55 and 0.52 .

Note that we do not have information for each individual bank on the share of assets abroad or at home. Because international banking markets are dominated by the large banks, the idiosyncratic shocks that we measure might also contain elements of idiosyncratic risk stemming from developments on international markets. This, however, does not affect the general validity of our approach because we are interested in the effects of idiosyncratic shocks affecting large banks on the domestic economy, irrespective of where these shocks originate. We also account for the effects of aggregate financial openness by allowing granular effects to differ between financially closed and open economies.

\subsection{Macroeconomic Growth}

To calculate macroeconomic growth, we use a country-sample which is sufficiently diverse to capture possible non-linearities and cross-country differences. We thus start from a dataset which includes a large set of countries. We keep those with complete strings of observations for at least ten years for key variables such as cross-border assets and liabilities, GDP growth, and domestic credit. We also include a set of standard growth regressors. Macroeconomic data for GDP, GDP per capita, domestic credit relative to GDP, inflation, school enrolment rates, the trade share, and government expenditure relative to GDP are taken from the World Development Indicators (WDI) by the World Bank.

This sample includes 80 countries for 14 years (1996-2009). Our dependent variable is growth of real GDP per capita. It is calculated by taking the first differences of log real GDP per capita. In order to prevent large outliers from affecting the results, growth rates are winsorized at the top and bottom percentile. The effects of winsorizing on sample 
means are minimal: winsorizing slightly increases the mean from $2.53 \%$, to $2.537 \%$ while it somewhat lowers the standard deviation from 3.63\% to 3.59\%. Table 1 shows that the mean growth of GDP per capita in the sample is $3 \%$ with a minimum growth rate of $-15 \%$ (Estonia 2009, Latvia 2009, Lithuania 2009) and a maximum growth rate of $+12 \%$ (China 2007, Kuwait 2003, Latvia 2006, Venezuela 2004).

Figure 1 shows the evolution of GDP growth and of the banking granular residual over time. The median growth rate of real GDP per capita is in the range of -3 to $5 \%$ in our sample, whereas GDP growth has been higher with median rates between -3 and $6 \%$. On average, GDP growth has trended upward since the mid-2000s, but this increase has reversed with a significant drop since the onset of the global financial crisis in 2007.

\subsection{Financial Openness}

To measure financial openness at the country-level, we use three de facto and two de jure measures. The first de facto measure is taken from the dataset on cross-border assets and liabilities by Lane and Milesi-Ferretti (2007). We extend their data for the period 20082009 using data from the International Investment Positions (IIP) which are available from the International Financial Statistics (IFS) by the IMF. ${ }^{3}$ In similar empirical models in the international trade literature, the degree of openness is measured as the sum of imports and exports relative to GDP. We thus use the sum of total foreign assets and total foreign liabilities relative to GDP as a proxy for financial openness.

As a second de facto measure, we use the sum of cross-border bank loans (assets and liabilities) relative to GDP. These data come from the IFS and are available for a smaller set of countries only. ${ }^{4}$ The maximum number of country-year observations is 922 in our baseline regression using total cross-border assets and liabilities as a measure of de facto financial openness. It declines to 562 if we include cross-border bank assets and liabilities as a measure of financial openness instead.

\footnotetext{
${ }^{3}$ Total foreign assets and liabilities comprise direct investment, portfolio investment, other investment like for example bank loans, and reserve assets and liabilities.

${ }^{4}$ More precisely, the data can be found in the International Investment Positions in the category "Other Investment”, sub-category “Loans”, “Banks”.
} 
The third de facto measure captures FDI in banking. We use information on the share of foreign banks in the number of all banks in a given country. Our measure is a count variable on the total number of banks (domestically and foreign owned) which we retrieve from Claessens and van Horen (2013).

Our first measure of de jure financial openness comes from Chinn and Ito (2006, 2008). These authors use the IMF's Annual Report on Exchange Restrictions and Regulations to construct a measure of capital controls. It is based on dummy variables which codify restrictions on cross-border financial transactions. The minimum number is -1.82 (financially closed), the maximum number is 2.46 (financially open).

In addition, we employ information on the de jure openness of the banking sector, namely an index of inflow restrictions and an index of outflow restrictions on financial credit which has been computed by Schindler (2009) from the Annual Report of Exchange Arrangements and Exchange Restrictions of the IMF for the period 1995-2005. The dataset has been extended by Klein (2012). and it is available for 72 out of the 83 countries which are included in our regression sample. ${ }^{5}$ The original indicators assume a value of 1 if there are restrictions on inflows or outflows of financial credits and a value of 0 if no such restrictions are imposed. We rescale the binary variables such that a value of zero indicates financial restrictions and a value of 1 indicates no restrictions on inflows or outflows of financial credit. Hence, all openness measures are scaled in the same way, and a higher value indicates a higher degree of financial openness.

Table 2 shows the correlations between our measures of financial openness. Correlations between total cross-border assets and cross-border assets of banks are quite high (0.74). Also, the measures of de jure openness are quite closely correlated with each other (around 0.7). The remaining correlations are much smaller and below 0.5. The main reason for these low correlations is that the de jure measures are less dispersed than the de facto measures of financial openness: most advanced economies have liberalized capital accounts. But the actual degree of financial openness may be very different across countries.

\footnotetext{
${ }^{5}$ We are grateful to Michael Klein for kindly providing an updated dataset on capital controls. For a description of a previous version of this data, see Klein (2012).
} 


\subsection{Additional Control Variables}

In addition to effects of granularity, we study the impact of credit to GDP for GDP growth. Credit to GDP is often used as a proxy for the size of the financial system. The larger - and the more developed - a banking sector is, the higher should be aggregate growth and the lower should be macroeconomic volatility because banks can allocate savings more efficiently. However, credit to GDP and thus leverage can also be taken as an indicator for overheating of the banking system, thus harming growth (Arcand et al. 2012, Cecchetti and Kharroubi 2012) and increasing macroeconomic volatility (Beck et al. 2013, Huinzinga and Zhu 2006). Historical evidence shows that leverage cycles have implications for macroeconomic instability and crises (Taylor 2012). Overall, the expected sign of the credit variable is thus not clear. Figure 3 shows the evolution of the credit to GDP ratio over time. Especially in the 2000s, credit to GDP has significantly increased.

We also include consumer price inflation, initial income as measured by log GDP per capita in 1996, the logarithm of the secondary school enrolment rate, the ratio of exports plus imports to GDP, and government final consumption expenditure relative to GDP as typical additional macroeconomic control variables.

\section{Regression Model and Results}

In order to analyze whether the impact of the Banking Granular Residual on the aggregate economy is related to the degree of financial openness, we proceed in three main steps. First, we estimate a panel regression model (Tables 4a - 4c) where we also include interaction terms for the BGR and financial openness. Second, we explore the link between granularity in banking, financial openness, and GDP growth by estimating a panel threshold model (Table 5). Moreover, we test the robustness of our findings with respect to time (Table 6). Finally, use instrumental variables regression to address potential endogeneity issues (Table 7). 


\subsection{Empirical Model}

With data on idiosyncratic credit growth shocks at hand, we regress aggregate growth on the banking granular residual, on macroeconomic characteristics, and on financial openness:

$$
\text { Growth }_{i, t}=\lambda_{t}+\beta_{1} B G R_{i, t}+\beta_{2}^{\prime} X_{i, t}+\beta_{3} F O_{i, t}+\varepsilon_{i, t}
$$

where Growth $h_{i, t}$ is growth of real GDP per capita, $\lambda_{t}$ is a vector of time fixed effects capturing global macroeconomic factors, and $B G R_{i, t}$ is the banking granular residual. $X_{i, t}$ is a vector of macroeconomic control variables which comprises the ratio of domestic bank credit to GDP, inflation, initial income, the log of the secondary school enrollment rate, the trade share and government final consumption expenditure relative to GDP. $F O_{i, t}$ includes measures of financial openness.

In a second step, we add interaction terms between the BGR and our six different measures of financial openness to equation (3), such that the model becomes

$$
\text { Growth }_{i, t}=\lambda_{t}+\beta_{1} B G R_{i, t}+\beta_{2}^{\prime} X_{i, t}+\beta_{3} F O_{i, t}+\beta_{4} B G R_{i, t} \cdot F O_{i, t}+\varepsilon_{i, t} .
$$

This allows us to study the interplay between the degree of financial openness and the effect of bank-specific shocks on GDP per capita growth.

\section{Granularity and aggregate growth}

Table 4 presents the regression results based on equations (3) and (4) for different de facto (Table 4a) and de jure measures of financial openness (Tables 4b and 4c) as explanatory variables.

Our results show that the banking granular residual matters. Shocks hitting large banks' asset growth do not cancel out in the aggregate but affect aggregate outcomes. The banking granular residual has a positive and significant impact on GDP growth with coefficient estimates between 0.03 and 0.09 . The results are very similar if the BGR based on banks' loans is used (not reported). Given that the standard deviation of GDP per capita growth is 0.04 while the standard deviation of the BGR based on assets is 0.07 (Table 1), the normalized beta coefficient for the BGR is between 0.05 and 0.16 
depending on the model specification. Or, in other words, about $5-16 \%$ of the variation in GDP per capita growth in our sample can be attributed to bank-specific shocks to asset growth. In a study using bank and firm-level data for the Japanese economy, Amiti and Weinstein (2013) find an even larger effect of granular shocks at the bank-level; in their study, bank-specific shocks account for approximately $40 \%$ of aggregate lending and investment fluctuations.

\section{Openness and growth}

De facto financial openness has a significantly negative impact on GDP growth in our sample (Table 4a). The economic significance of the impact of cross-border assets and liabilities and of foreign bank loans is larger than the economic significance of the BGR with normalized beta coefficients of 0.2 . The share of foreign banks is insignificant.

The result that greater openness lowers short-run growth may seem surprising, given that increased financial openness should improve the reallocation of capital across countries and thus stimulate growth. However, it links into a large body of literature analyzing the fact that capital does not necessarily flow from rich to poor countries (the "Lucas Paradox") and that institutional constraints may prevent an efficient relocation of capital across countries (Alfaro et al. 2008). Hence, we have checked whether this result is driven by countries which have weaker financial institutions or lower financial development such that increased financial openness cannot unfold growth-enhancing effects. When including interactions between financial openness and credit to GDP as in Kose et al. (2011), the direct effect of financial openness becomes insignificant in many cases. When including, both, the interaction between financial openness and credit to GDP and the interaction between financial openness and the square of credit to GDP, we find that financial openness measured by cross-border bank loans has a negative effect on growth if financial depth is low. As credit to GDP increases, the effect gets positive. For very high levels of credit to GDP, the effect gets weaker again. Thus, the impact of financial openness on growth depends on the level of credit over GDP of an economy. Are granular effects weaker or stronger in financially open economies?

We answer the question whether financial openness affects the strength of granular effects by including interactions between the different openness measures and the 
banking granular residual. These interaction terms are significant for total assets and liabilities and thus for a broader measure of openness. They are insignificant for foreign bank loans relative to GDP and for the shares of foreign banks. This finding indicates that different types of international capital flows are needed in order to weaken the link between bank-specific asset or credit shocks and aggregate outcomes. Besides foreign bank lending, other substitutes for domestic credit seem to be useful to shield an economy from idiosyncratic bank-level shocks.

Figure 4 illustrates the marginal effect of the BGR on GDP growth depending on the level of financial openness (Column 3 of Table 4a). The relationship between the BGR and aggregate growth is decreasing in the share of foreign assets and liabilities. For low levels of financial openness, the BGR has a positive and significant impact on GDP growth. As foreign openness increases, the effect of the BGR gets weaker. For values of financial openness above roughly 3.9, the marginal effect of the BGR on GDP per capita turns insignificant. Typical countries which fall in this group are Belgium, the Netherlands, Sweden or the UK and thus high-income countries. Countries which fall in the group below this threshold are, for example, Bulgaria, China, Mexico, but also Spain and the United States.

De jure measures of financial openness do not matter for GDP growth (Table 4b). One reason is that the measures of de jure openness are less dispersed than the de facto measures. The maximum value of the de jure measures is observed much more frequently than the highest values of de facto openness are. Hence, the de jure openness indicators are less differentiated and do not allow for studying the effects of the high levels of openness. For example, the Chinn-Ito index for Germany has taken on the maximum value of de jure capital account openness (2.46) across the entire sample period, whereas German de facto openness, measured by foreign assets plus liabilities relative to GDP, has increased by about 150\% between 1996 and 2009.

Most of the countries in our sample have not changed the degree of financial openness over time. To account for the persistence of the de jure measure of financial openness, we re-run the regression models presented in Table $4 \mathrm{~b}$ on the sub-sample of countries which experienced changes in the respective de jure measures at least once in the sample period. 
This specification is more in line with Henry (2007) who points out that the neoclassical growth model suggests a temporary increase in growth as a result of a change in financial openness and a permanent level effect. Using data for countries that changed the degree of financial openness only significantly reduces sample size. Table 4c has the regression results. While the effect of the BGR turns insignificant if the Chinn-Ito index is interacted with the BGR (Column 3), it remains positive and significant for the inflow and outflow restriction variables (Columns 4-7). The direct effects of the de jure financial openness measures remain insignificant.

\section{Control variables}

We control for standard determinants of growth as well as the ratio of credit over GDP. This ratio is highly significant and negative with point estimates between 0.016 and 0.035. As the standard deviation of credit to GDP is 0.58 and the standard deviation of GDP growth is 0.04 , the beta coefficient lies in the range of 0.23 and 0.5 . Hence, the fraction of GDP growth that can be explained by the level of credit to GDP is much higher than the fraction explained by the BGR. We obtain similar results in unreported regressions using private credit by deposit money banks relative to GDP.

The sign of credit to GDP clearly supports the interpretation of this variable as a proxy for leverage in the financial sector: the higher leverage, the lower is growth. If credit to GDP was solely a proxy for financial development, we would expect to find a positive impact on growth. In this vein, Beck et al. (2013) present empirical evidence for 77 countries over the period 1980-2007 which suggest positive effects of credit to GDP on GDP per capita growth for medium- and long-run averages of growth rates. Our analysis differs because we look at year-to-year growth of GDP. Hence, we have re-run our model for medium- and long-run averages instead. ${ }^{6}$ In models using the cross-sectional, longrun variation in growth across countries or using non-overlapping 4-year averages of the data, credit over GDP is insignificant. Hence, the negative growth effect is confined to short-run fluctuations of growth only. The direct effect of financial openness on growth remains negative and significant for foreign assets plus liabilities to GDP and for foreign

\footnotetext{
${ }^{6}$ The regression tables are available upon request.
} 
bank credit in the regressions using 4-year averages of the data. The coefficient on the BGR remains positive and significant in the model specifications where foreign assets plus liabilities to GDP or the Chinn-Ito index is included. In the cross-sectional regressions, the effects of financial openness and the BGR become insignificant. Results for the remaining determinants of growth are largely in line with expectations (Table 4). Higher inflation reduces growth, which is in line an interpretation of inflation as a measure of uncertainty whichdepresses GDP growth (Kremer et al. 2013). As expected, the impact of initial income is mostly negative but insignificant, while a higher secondary school enrolment rate fosters growth. Trade has a slightly positive and significant impact, and government expenditure relative to GDP harms growth. This is in line with the results presented by Beck et al. (2013) for medium and long-term growth. Using, again, cross-sectional regressions using average values of all variables across our entire sample period show negative and significant effects of initial income on GDP per capita growth while the effect of the share of secondary school enrolment is positive as in the year-by-year regression. All other variables, do not significantly affect long-run growth in our sample. When running panel regression across non-overlapping 4-year averages of the data for the period 1996-2007, growth increases in schooling and trade openness while it is reduced the higher initial income and inflation are.

Robustness with respect to time

How robust are our results to modifications of the time period? In particular, does including or excluding the crises years affect our results? In Table 5, we address this question by estimating the model specification from Table 4a, Column 3 for (i) 19962000, 2001-2005 and 2006-2009, for (ii) the 1990s and the 2000s, and (iii) for the precrisis and crisis period (2007-2009). The negative impact of credit to GDP is clearly reminiscent of the pre-crisis period. The same is true for the direct effect foreign assets plus liabilities relative to GDP. For the years since 2007, the impact of these two variables is insignificant. The impact of the banking granular residual also depends on the time period. Its positive link to aggregate growth is, however, driven by the more recent period and cannot be observed when looking at the period until the mid-2000s only. This 
explains why concerns about bank size and the systemic effects of large banks have become more prevalent in recent years.

In unreported regressions, we drop each year, one-by-one, from the regressions based on Table 4a, Column 3 in order to check whether our findings are driven by individual years. The effect of the BGR stays positive and significant throughout, while the effect of its interaction with financial openness remains negative and significant. Also, the results for domestic credit to GDP, inflation, initial income, and foreign assets plus liabilities relative to GDP are unaffected from excluding individual years from the sample.

In sum, the results from our baseline regressions are in support of granularity effects: variation in aggregate growth can be explained by bank-level, idiosyncratic shocks, weighted by banks' market shares. GDP growth is weaker in countries with high credit to GDP and thus high leverage. Financial openness as measured by different de facto measures mitigates growth. De jure financial openness has no significant impact on aggregate output growth. Also, granular effects tend to be weaker in financially open economies.

\subsection{Testing for Non-Linearities}

\subsection{Sample Splits}

In unreported regressions, we have experimented with different sample splits into groups of financially open and financially closed countries. The difficulty with this approach is that any classification of countries is inevitably arbitrary. Tables 3a and b provide lists of the countries that fall into each of the categories for our two key measures of de facto and de jure openness.

Using a de facto measure to split the sample, all countries which have a ratio of foreign assets plus liabilities to GDP below 2.21 fall into the subset of "financially closed" economies. However, these are not necessarily countries with restrictions on cross-border financial transactions. Italy, for instance, is a country with a degree of de facto financial openness close to the sample mean. For de jure financial openness, all countries with a value of the Chinn-Ito index below 1.01 fall into the subset of "financially closed" 
countries. The Chinn-Ito measure of financial openness provides a more accurate picture of financial openness in a regulatory sense, and it is also the less dispersed measure. Table 3a groups countries with respect to de facto financial openness. There are much more countries which have an average stock of foreign assets plus liabilities relative to GDP below the sample mean („financially closed“) than countries which have de facto financial openness above the sample mean. When splitting up countries according to the mean of de jure openness (Table 3b), many countries switch to the group of financially open economies.

In sum, results based on sample splits are rather ad hoc, and results are very sensitive to the specific choice we made with regard to classifying entire countries. We thus refrain from reporting and interpreting these results which, of course, are available upon request.

\subsection{Panel Threshold Model}

Having seen that the link between bank-level and aggregate growth varies with financial openness, we will now shed more light on possible breakpoints in this relationship. For this purpose, we estimate a panel-threshold model which endogenously allows estimating possible threshold effects of financial openness. The panel-threshold approach takes into account that the effect of the BGR on GDP growth may depend on the degree of financial openness. In each sub-domain of financial openness identified, the relationship between the BGR and GDP growth is linear. The slope coefficients are allowed to differ, which was not possible in the regression approach using interactions above.

In order to study whether the link between the BGR and growth differs across different ranges of financial openness, we estimate the following regression model:

Growth $_{i, t}=\lambda_{t}+\delta_{1} I\left(T H_{i, t} \leq \gamma\right)+\beta_{1} B G R_{i, t} I\left(T H_{i, t} \leq \gamma\right)+\beta_{2} B G R_{i, t} I\left(T H_{i, t}>\gamma\right)+\beta_{3}^{\prime} X_{i, t}+\varepsilon_{i, t}$ where $\lambda_{t}$ are time-fixed effects, $X_{i, t}$ is a vector of control variables, and $T H_{i, t}$ is the threshold variable (financial openness). $I(\cdot)$ is an indicator function which equals one if the condition in brackets is true and zero otherwise. The first indicator function equals one if the threshold variable, $T H_{i, t}$, is smaller than the threshold $\gamma$. The second indicator function takes the value of one if the threshold variable is greater than $\gamma$. Thus, the 
indicator functions split up the observations of $B G R_{i, t}$ into two regimes, depending on the threshold $\gamma$. The slope coefficient on $B G R_{i, t}$ is allowed to differ across the two regimes. If the threshold variable is below $\gamma$, the effect of bank-level shocks on aggregate growth is given by $\beta_{1}$, while it is given by $\beta_{2}$ if the threshold variable assumes values larger than $\gamma$. Following Bick (2010), we control for differences in the regime-specific intercept by including a regime-specific constant $\delta_{1}$.

The panel threshold model is estimated in two steps (Hansen 1999). In a first step, the threshold $(\gamma)$ is estimated by least squares. In a second step, we estimate the slope coefficients ( $\beta_{1}$ and $\beta_{2}$ ) using this threshold estimate. ${ }^{7}$

Following Hansen (1999, 2000), confidence intervals for the threshold estimate are based on the likelihood ratio statistic for testing the null hypothesis that the threshold $\gamma$ equals its true value. The asymptotic confidence interval for $\gamma$ is given by the "non-rejection region” for this test on $\gamma$, i.e. it is given by the set of values for which the likelihood ratio statistic does not exceed the critical value. Inference on the regime-dependent slope coefficients can be performed as if the estimated threshold were the true value (Hansen 1999: 352).

Table 6 has the regression results based on an unbalanced panel for the period 1996-2009. We run threshold regressions for all de facto measures of financial openness and for the Chinn-Ito index. Restrictions on financial credits are left out, because they are binary variables. The effects of the macroeconomic control variables are qualitatively the same as in the regressions presented above.

For foreign assets plus liabilities to GDP as well as for the share of foreign banks, we confirm that the impact of the BGR on GDP growth depends on financial openness. If these two measures of de facto financial openness are below their estimated thresholds, the BGR and growth are positively linked. The threshold estimate is 2.8 for foreign assets

\footnotetext{
7 Our estimation code heavily draws on Matlab-codes kindly provided by Alexander Bick (see http://www.wiwi.uni-frankfurt.de/professoren/fuchs/bick/). The model can be extended for more than one threshold in a straightforward way.
} 
plus liabilities to GDP which is a little higher but close to the sample mean. For the share of foreign banks, the estimated threshold of 0.09 is significantly lower than the sample mean (0.29). If financial openness is higher than the estimated thresholds, GDP growth is not affected by bank-specific shocks. This finding is in line with the results using interaction terms discussed above (Table 4a): Countries with a low degree of de facto financial openness are affected more by bank-level shocks.

If we take the Chinn-Ito index as a threshold variable, the BGR has a positive and significant effect on GDP per capita growth if the Chinn-Ito index is larger than -0.9. This threshold is very low compared to the sample mean (1.01). Hence, as the dispersion of the Chinn-Ito index is very low compared to the de facto openness measures, the effect is driven by countries with a rather low degree of financial openness.

When taking the BGR based on banks loans as a regime-dependent regressor (not reported), the results point into the same direction: In this case, the BGR has a positive and significant effect on growth if the three de facto measures of financial openness are below their estimated thresholds. For the Chinn-Ito index as a threshold variable, the BGR positively impacts on growth for values of the index above -0.9 , as for the BGR based on bank assets.

\subsection{Instrumental Variable Regressions}

Endogeneity of the banking granular residual with regard to macroeconomic volatility should not be a concern in our model: The idiosyncratic shocks are deliberately cleaned from macroeconomic effects, and market structure in banking does not vary with the cycle.

Yet, the degree of financial openness as well as credit to GDP, and the remaining macroeconomic control variables (initial income, the trade share, government consumption expenditures relative to GDP and inflation) might be endogenous with regard to GDP per capita growth. Countries may, for instance, close their financial systems in times of crisis or they may export and import more when growth is high. In Table 7, we thus estimate the regression models (without interactions) from Table 4a and $4 \mathrm{~b}$ using instrumental variables regressions. We use the third lags of each potentially 
endogenous variable as instruments, apart from inflation where the first lag is used. ${ }^{8}$ In addition, we use heteroskedasticity-based generated instruments as proposed by Lewbel (2012) and implemented in Stata by Baum and Schaffer (2012). Lewbel's method allows constructing instruments as simple functions of the model variables when no external instruments are available. It can also be used, as we do here, to add heteroscedasticitybased instruments to the set of external instruments in order to increase efficiency. Table 7 shows that the BGR turns insignificant in the regressions using foreign bank loans or the Chinn-Ito index as (instrumented) openness measures. For all remaining regressions, the effect of the BGR on growth stays positive and significant. For our different measures of financial openness, the IV-results point to a negative and significant effect on growth for all measures apart from the share of foreign banks. Hence, this result is even more pronounced than in the baseline OLS-regressions presented above. The impact of credit to GDP remains negative if instrumented, but turns insignificant in many cases. The degree of secondary school enrollment significantly increases growth throughout, whereas initial income has a negative and significant effect which points to convergence. Inflation does not affect growth when instrumented.

\section{Summary}

We have explored how the structure and the openness of the banking system affect aggregate growth. Our special focus has been on granular effects. Granularity arises if the market structure in an industry is highly concentrated such that very few large firms coexist with many small firms. Such size patterns prevail in banking. In this case, idiosyncratic shocks to large banks do not have to cancel out across a large number of banks in the aggregate. We find that bank-specific shocks matter: The banking granular residual has a positive and significant impact on the growth of real GDP per capita. Hence, the higher is the size concentration in banking markets or the larger idiosyncratic shocks, the stronger are linkages between bank-level and macroeconomic growth fluctuations.

\footnotetext{
8 The lags of the different variables are chosen such that they are correlated with at least one of the potentially endogenous regressors in the first stage regressions.
} 
We find that financial openness, measured through the ratio of cross-border assets and liabilities over GDP is associated with lower growth. What matters is the actual, de facto, degree of financial openness. All de jure measures of openness, which measure the presence of capital controls, are insignificant. Financial openness also affects the strength of granular effects. Effects of bank-level shocks tend to be of little importance for macroeconomic outcomes in financially more open countries. Financially closed countries experience stronger granular effects from the banking sector.

A higher ratio of bank credit relative to GDP - and thus a higher degree of "leverage" in the banking system - harms short-run GDP growth. The potential destabilizing effect of high leverage is acknowledged in the macroprudential policies, and credit to GDP serves as a basis for the calculation of countercyclical capital buffers for banks (Houben et al. 2012). Our results show that this result is driven by the pre-crisis period; the effect of leverage on growth has been insignificant for the period 2006-2009.

Our results imply that there are different channels through which the linkages between bank-level shocks and macroeconomic outcomes can be weakened. First, reducing the degree of size concentration in banking mitigates the importance of bank-level shocks for the macroeconomy. Higher competitive pressures in the banking sector could thus extenuate the pass-through of bank-level shocks to the real economy. This, in turn, would reduce granular effects and hence macroeconomic fluctuations. Second, higher competitive pressure could also increase idiosyncratic risk at bank level because compressed profit margins could induce banks to move into riskier activities. Accounting for this endogenous link between market structure in banking and (bank-level) risk is an issue that we have not addressed in this paper. Third, the increasing fragmentation of financial markets that we observe as a response to the financial crisis could aggravate granular effects. 


\section{References}

Alfaro, L., Kalemli-Ozcan, S., and V. Volosovych (2008). Why Doesn't Capital Flow from Rich to Poor Countries? An Empirical Investigation. Review of Economics and Statistics 90(2): 347-368, May.

Amiti, M. and D.E. Weinstein (2013): How much do bank shocks affect investment? Evidence from matched bank-firm loan data, NBER Working Paper No. 18890, Cambridge, MA.

Arcand, J.-L., Berkes, E., and U. Panizza (2012). Too much finance?. IMF Working Paper 12/161. Washington DC.

Baum, C. and Schaffer (2012). IVREG2H: Stata module to perform instrumental variables estimation using heteroskedasticity-based instruments.Statistical Software Components, Boston College, Department of Economics.

Beck, T., Degryse, H., and S. Kneer (2013). Is more finance better? Disentangling intermediation and size effects of financial systems. Journal of Financial Stability, forthcoming.

Bick, A. (2010). Threshold Effects of Inflation on Growth in Developing Countries, Economics Letters 108(2): 126-129.

Blank, S., C.M. Buch, and K. Neugebauer (2009). Shocks at large banks and banking sector distress: The Banking Granular Residual. Journal of Financial Stability 5(4): 353-373.

Bremus, F. (2013). Cross-Border Banking, Bank Market Structures and Market Power: Theory and Cross-Country Evidence, draft, DIW Berlin, July.

Bremus, F., C.M. Buch, K.N. Russ, and M. Schnitzer (2013). Big Banks and Macroeconomic Outcomes: Theory and Cross-Country Evidenceof Granularity, NBER Working Paper No. 19093, Cambridge, MA.

Buch, C.M., and K. Neugebauer (2011). Bank-specific shocks and the real economy. Journal of Banking and Finance 35(8): 2179-2187.

Cecchetti, S. and E. Kharroubi (2012). Reassessing the impact of finance on growth. BIS Working Paper 381. Basel.

Chinn, M.D., and H. Ito (2006). What Matters for Financial Development? Capital Controls, Institutions, and Interactions. Journal of Development Economics 81(1): 163-192.

Chinn, M.D., and H. Ito (2008). A New Measure of Financial Openness. Journal of Comparative Policy Analysis 10(3): 309-322.

Claessens, S. and N. van Horen (2013). Foreign banks: Trends and Impact. Journal of Money, Credit, and Banking, forthcoming.

De Blas, B., and K. N. Russ (2010). FDI in the Banking Sector. National Bureau of Economic Research. NBER Working Paper 16029. Cambridge MA. 
De Blas, B., and K.N. Russ (2013). All Banks Great, Small, and Global: Foreign competition and loan pricing. International Review of Economics and Finance, forthcoming, volume 26, April, 4-24.

Di Giovanni, J., and A. Levchenko (2009). Trade Openness and Volatility. The Review of Economics and Statistics 91(3): 558-585.

Di Giovanni, J., A.A. Levchenko, and R. Ranciére (2011). Power laws in firm size and openness to trade: Measurement and implications, Journal of International Economics 85(1): 42-52.

Gabaix, X. (2011). The Granular Origins of Aggregate Fluctuations. Econometrica 79(3): 733-772.

Hansen, B.E. (1999). Threshold effects in non-dynamic panels: estimation, testing, and inference. Journal of Econometrics 93, 345-368.

Hansen, B.E. (2000). Sample Splitting and Threshold Estimation, Econometrica 68(3): 575-603.

Henry, P.B. (2007). Capital Account Liberalization: Theory, Evidence, and Speculation. Journal of Economic Literature Vol. XLV: pp. 887-935, December.

Houben, A., R. van der Molen, and P. Wierts (2012). Making Macroprudential Policy Operational. Banque Centrale du Luxembourg. Revue de Stabilitè Financiere: 1325.

Huizinga, H. and D. Zhu (2006). Financial Structure and Macroeconomic Volatility: Theory and Evidence. CEPR Discussion Paper 5697. London.

Klein, M. (2012). Capital Controls: Gates versus Walls, NBER Working Paper No. 18526, Cambridge, MA.

Klein, M., and G. Olivei (2008), Capital Account Liberalization, Financial Depth, and Economic Growth. Journal of International Money and Finance 27(6): 861-75.

Kose, M.A., E.S. Prasad, and M.E. Terrones (2003). Financial Integration and Macroeconomic Volatility. IMF Working Paper 03/50. Washington D.C.

Kose, M.A., E. Prasad, K. Rogoff, and S.-J. Wei (2009). Financial Globalization: A Reappraisal. IMF Staff Papers 56(1): 8-62.

Kose, M.A., E.S. Prasad, and A.D. Taylor (2011). Threshold Effects in the Process of International Financial Integration. Journal of International Money and Finance 30(1):147-179.

Kremer, S., Bick, A. and D. Nautz (2013). Inflation and growth: new evidence from a dynamic panel threshold analysis. Empirical Economics 44(2), 861-878, April.

Lane, P.R., and G.M. Milesi-Ferretti (2007). The External Wealth of Nations Mark II. Journal of International Economics 73: 223-250.

Lewbel (2012). Using Heteroscedasticity to Identify and Estimate Mismeasured and Endogenous Regressor Models. Journal of Business and Economic Statistics 30(1): 67-80. 
Melitz, M. J. (2003). The Impact of Trade on Intra-Industry Reallocations and Aggregate Productivity. Econometrica 71(6): 1695-1725.

Pockrandt, J., and S. Radde (2012). Need for Reform of EU Banking: Decoupling the Solvency of Banks and Sovereigns. DIW Economic Bulletin, 11:11-18.

Rose, A.K., and T. Wieladek (2011). Financial Protectionism: the First Test. National Bureau of Economic Research. NBER Working Paper 17073. Cambridge, MA.

Schindler, M. (2009). Measuring Financial Integration: A New Dataset. IMF Staff Papers Vol 56 (1), Washington, D.C..

Taylor, A. M. (2012). The Great Leveraging. NBER Working Paper No. 18290, Cambridge, MA. 


\section{Data Appendix}

List of countries: Algeria, Argentina, Australia, Austria, Bangladesh, Belgium, Benin, Bolivia, Brazil, Bulgaria, Cameroon, Canada, China, Colombia, Costa Rica, Croatia, Czech Republic, Denmark, Dominican Republic, Egypt, El Salvador, Estonia, Finland, France, Georgia, Germany, Ghana, Greece, Guatemala, Honduras, Hungary, India, Indonesia, Ireland, Israel, Italy, Japan, Jordan, Kenya, Korea, Rep., Kuwait, Latvia, Lithuania, Malawi, Malaysia, Mali, Mauritius, Mexico, Mozambique, Nepal, Netherlands, Nicaragua, Norway, Pakistan, Panama, Paraguay, Peru, Philippines, Poland, Portugal, Romania, Russia, Rwanda, Senegal, Slovak Republic, Slovenia, South Africa, Spain, Sudan, Sweden, Switzerland, Thailand, Tunisia, Turkey, Uganda, United Kingdom, United States, Uruguay, Venezuela, Zimbabwe.

Banking granular residual: To compute the banking granular residual, we use bank-level data on total net credits and total assets from the Bankscope database for the period 19952009.

Capital controls: We use the Chinn-Ito Index as a de jure measure for financial openness. This variable measures a country's degree of capital account openness and is available for the period 1970-2010 and 182 countries. It ranges from -1.82 to 2.46 with a sample mean of zero. The smaller the Chinn-Ito Index, the lower (de jure) financial openness.

Credit to GDP: Domestic credit provided by the banking sector (in \% of GDP) is taken from the WDI.

Foreign bank loans: Sum of foreign bank loans (assets and liabilities) relative to GDP, International Investment Positions, IFS.

GDP growth, GDP per capita: in constant 2000 US-Dollars, WDI.

Government expenditure (in \% of GDP): Final consumption expenditure of the central government as a share of GDP, WDI.

Inflation: US annual CPI -inflation (2005=100), WDI.

Inflow/outflow controls on financial credit: Indexes on inflow and outflow restrictions on commercial credit have been provided by Michael Klein. The measures are based on the Annual Report of Exchange Arrangements and Exchange Restrictions from the IMF and take on a value of zero if there are no restrictions on financial credit in place. A value of one reflects restrictions. We rescale this variable such that it can be interpreted in line with the other openness measures. That is, a value of zero means that restrictions are in place and hence financial openness is low, while a value of one means that no such restrictions are in place and hence financial openness is higher.

Schooling: Gross secondary school enrolment rate, WDI.

Share of foreign banks: We compute the number of foreign banks relative to all banks in a given country and year from data provided by Claessens and van Horen (2013).

Total foreign assets and liabilities: We use data on total foreign assets and liabilities in US-Dollars from the database by Lane and Milesi-Feretti (2007) which is available for the period 1970-2007 for 178 countries. We extend the time series for the year 2008 and 2009 using corresponding data from the International Financial Statistics by the IMF. We 
deflate the data using the US-Consumer Price Index $(2005=100)$ from the World Development Indicators.

Trade share: Sum of exports and imports relative to GDP, WDI. 


\section{Figure 1: GDP and Idiosyncratic Growth}

This figure shows growth in real GDP per capita, real GDP, and idiosyncratic growth at the bank-level, once based on banks total assets and once based on credit. The banking granular residual is the weighted average of idiosyncratic asset (credit) growth shocks where the weights correspond to the market shares of each bank. Credit growth shocks are the difference between bank j's asset (credit) growth and the country mean excluding bank $j$.

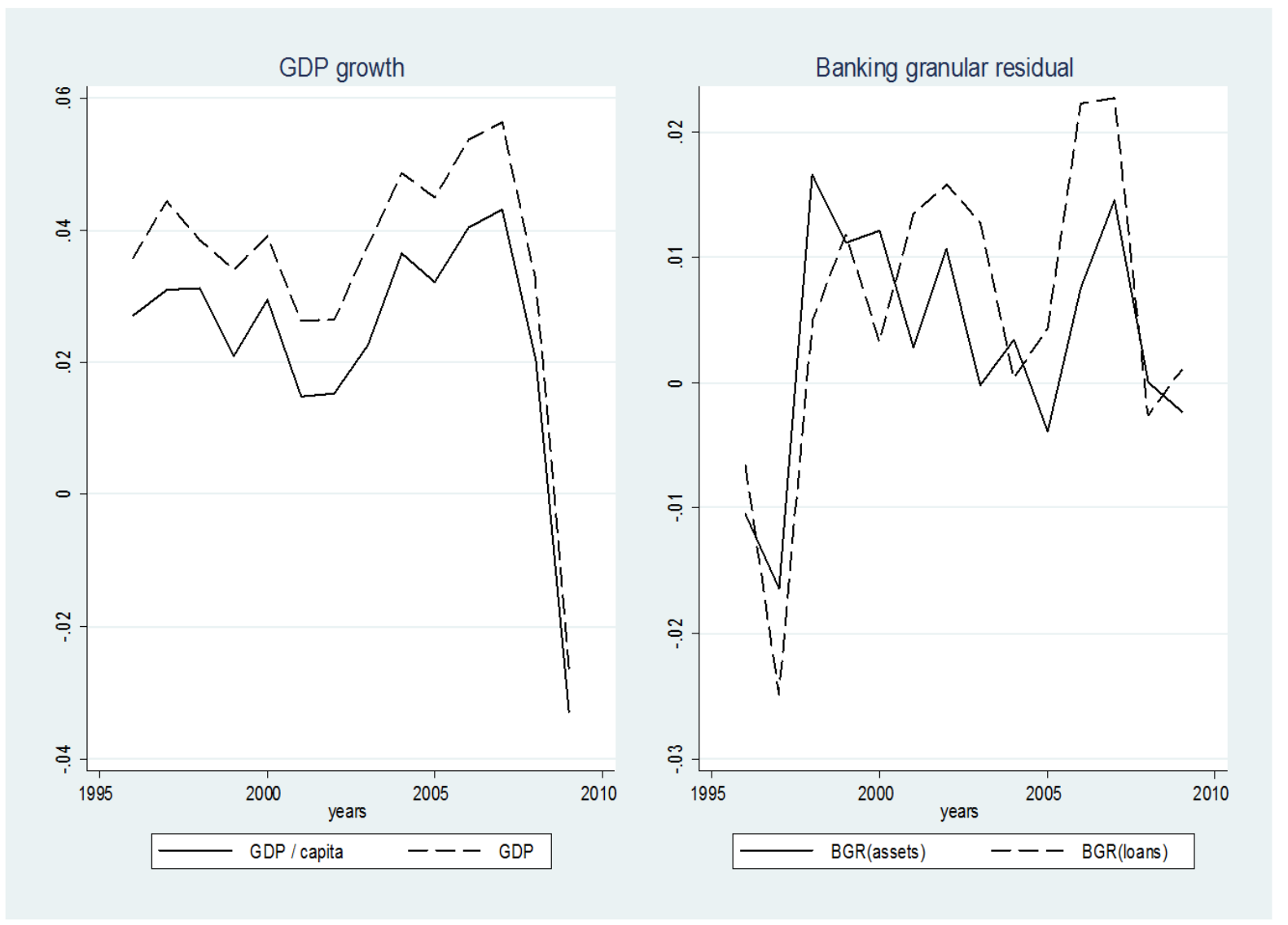

Source: World Development Indicators, Bankscope, own calculations. 


\section{Figure 2: Financial Openness}

This figure shows the evolution of different measures of financial openness across our sample period. The left panel plots three de facto measures of financial openness, namely total foreign assets plus liabilities relative to GDP, total foreign bank loans (assets plus liabilities) relative to GDP, and the share of foreign banks in the total number of banks. The right panel plots the Chinn-Ito index of capital controls, the index of financial inflow openness and the index of financial outflow openness, i.e. three de jure measure of financial openness. The graph shows the mean values for the full country sample, with all variables being normalized by their values in 1996 in order to enhance visibility.
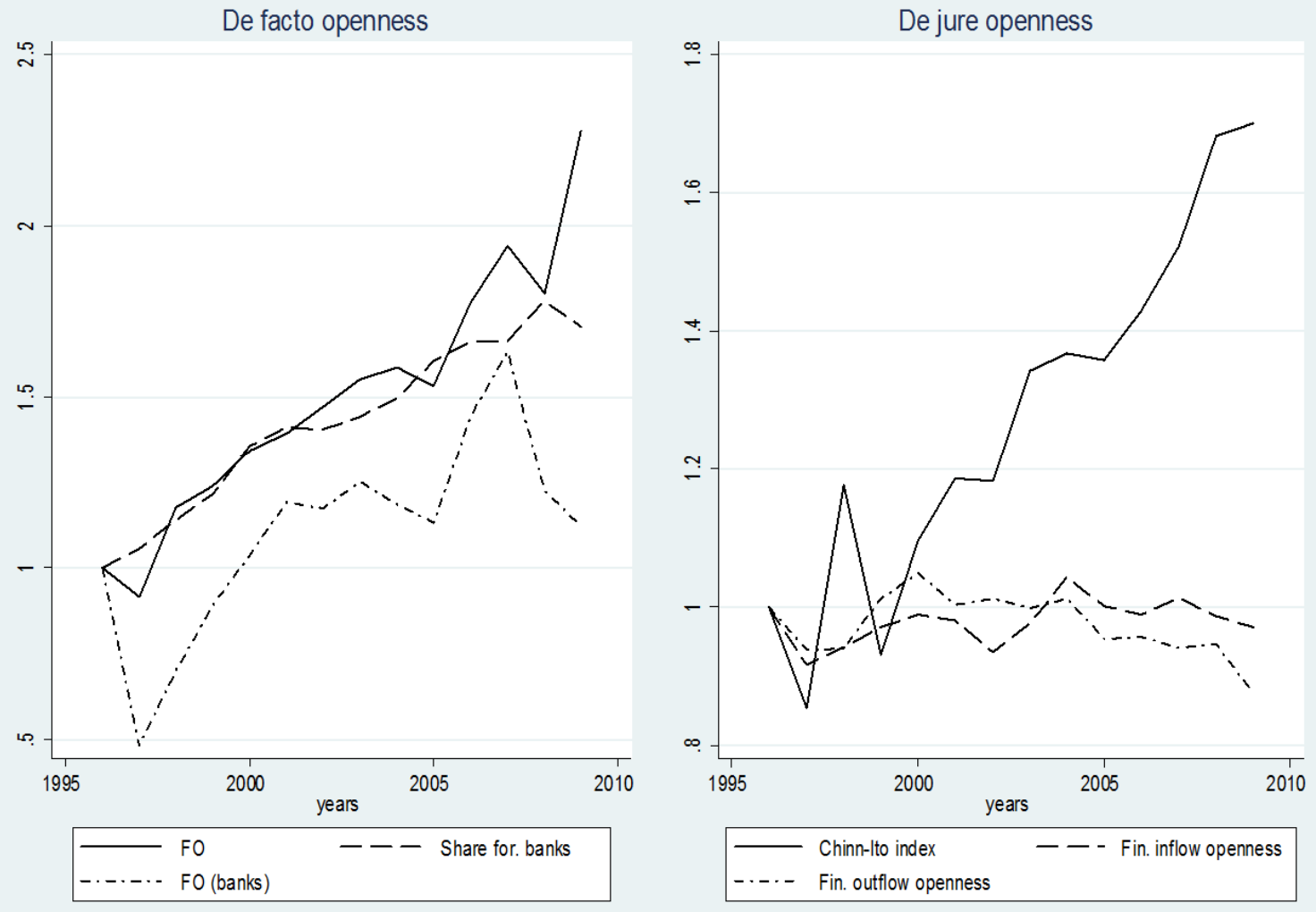

Source: International Financial Statistics, Claessens and van Horen (2013), Chinn and Ito (2008), Klein (2012), own calculations. 


\section{Figure 3: Banking Market Structures}

This figure shows the evolution of aggregate leverage, i.e. the mean share of domestic credit to GDP taken from the World Development Indicators at the left panel. The right panel plots the sample mean of the three-bank concentration ratio from the Financial Structures Database across the sample period.

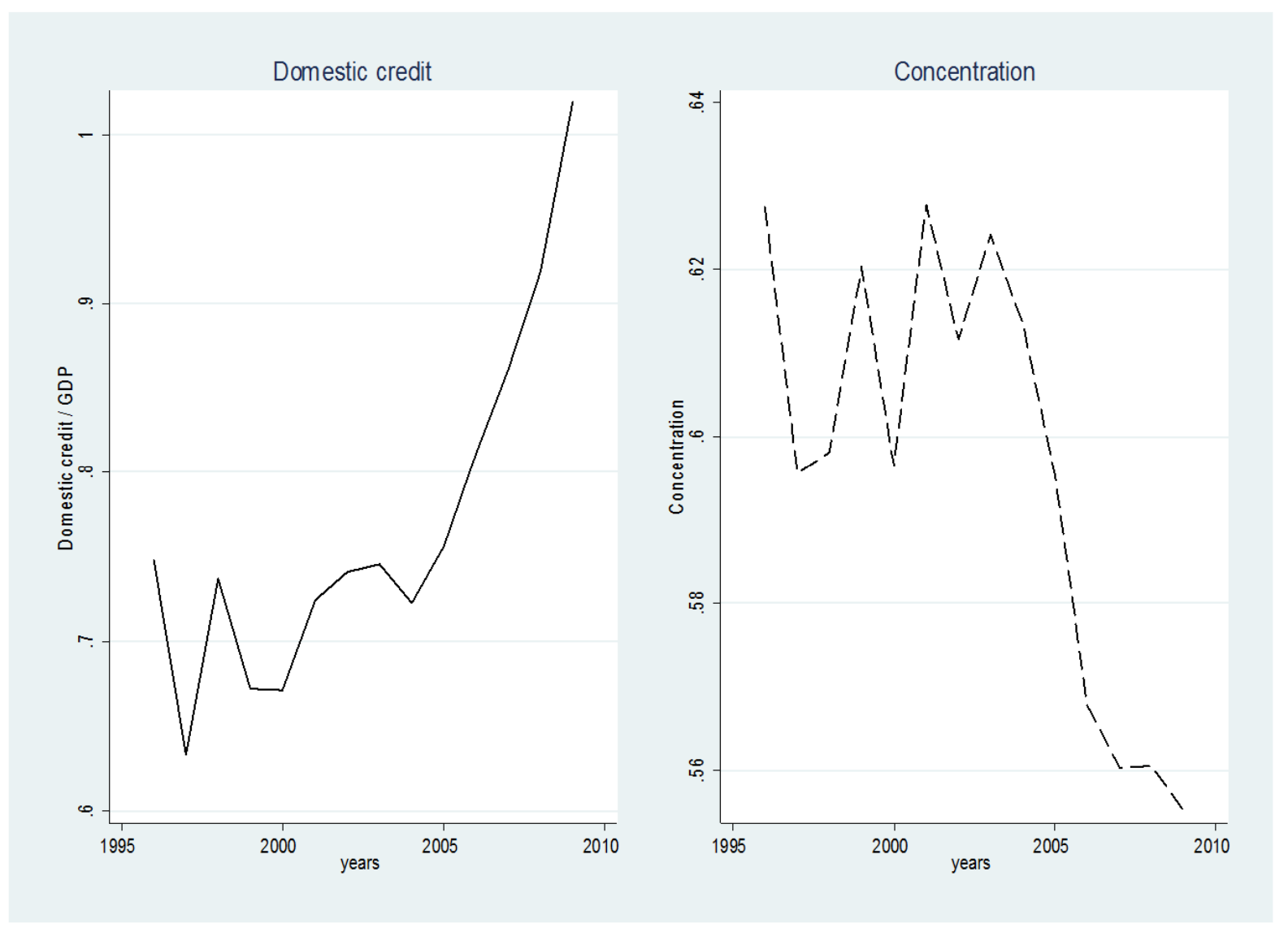

Source: World Development Indicators, Financial Structures Database, own calculations. 


\section{Figure 4: Interaction between the Banking Granular Residual and Financial Openness}

This figure shows the marginal effect of the Banking Granular Residual (BGR) on GDP growth for different levels of financial openness, measured as the ratio of foreign assets plus liabilities to GDP. The computation of the marginal effect depending on de facto financial openness is based on the regression in Table 4a, Column (3). Dashed lines show the 95\%-confidence bands.

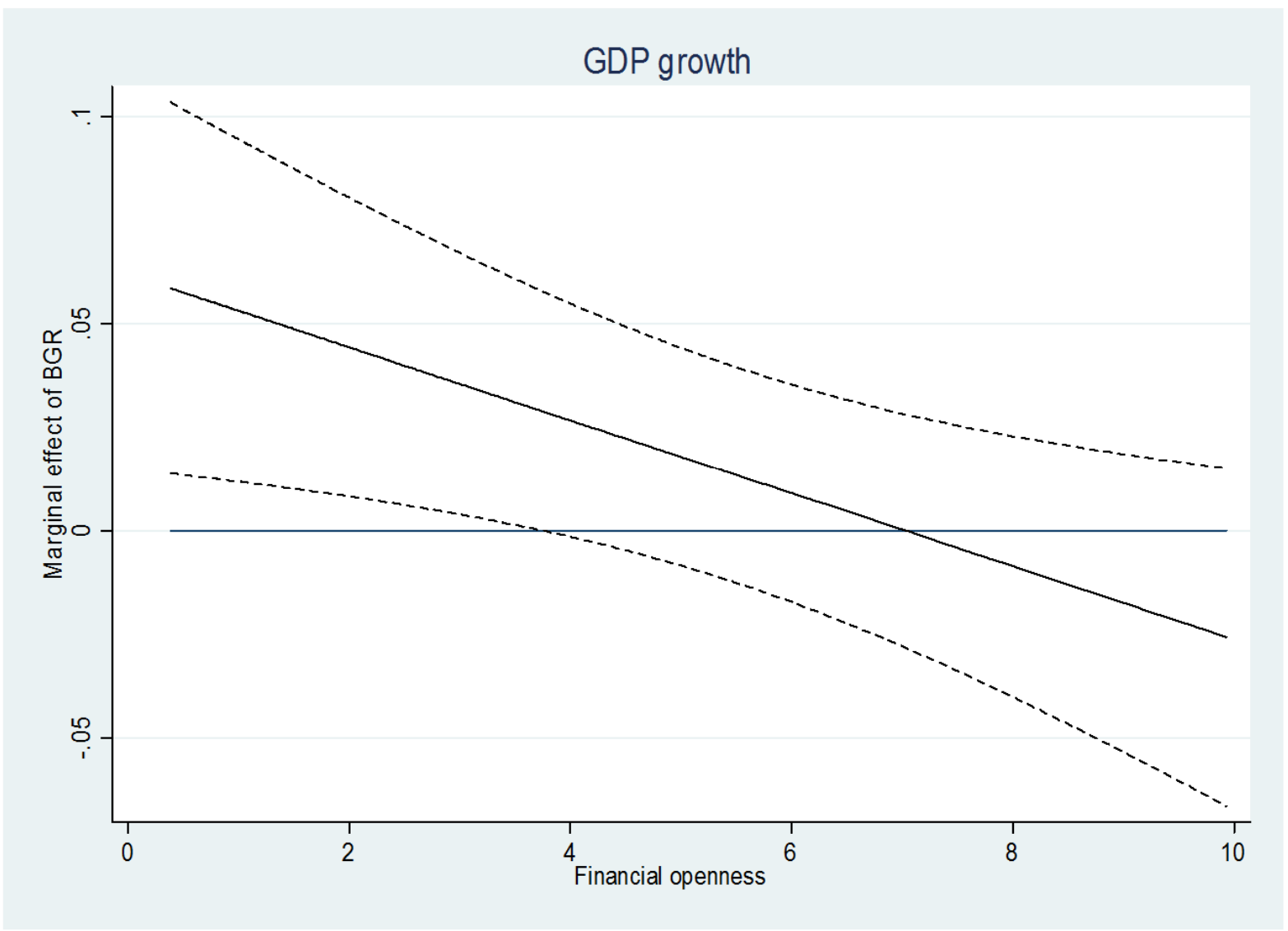




\section{Table 1: Descriptive Statistics}

These descriptive statistics are based on the baseline regression sample (Table 4)

\begin{tabular}{|c|c|c|c|c|c|}
\hline & Obs & Mean & Std. Dev. & Min & Max \\
\hline \multicolumn{6}{|l|}{ Macroeconomic growth } \\
\hline GDP per capita growth & 922 & 0.03 & 0.04 & -0.15 & 0.12 \\
\hline GDP growth & 922 & 0.04 & 0.04 & -0.13 & 0.15 \\
\hline \multicolumn{6}{|l|}{ Banking granular residual } \\
\hline BGR (loans) & 922 & 0.01 & 0.09 & -0.48 & 0.52 \\
\hline BGR (assets) & 922 & 0.00 & 0.07 & -0.55 & 0.46 \\
\hline \multicolumn{6}{|l|}{ De facto financial openness } \\
\hline (Foreign assets + liabilities) / GDP & 922 & 2.21 & 2.73 & 0.39 & 30.93 \\
\hline Foreign bank loans (assets + liabilities) / GDP & 562 & 0.29 & 0.48 & 0.00 & 3.11 \\
\hline Share of foreign banks in the number of all banks & 703 & 0.30 & 0.25 & 0.00 & 0.93 \\
\hline \multicolumn{6}{|l|}{ De jure financial openness } \\
\hline Chinn-Ito index of capital controls & 922 & 1.01 & 1.49 & -1.86 & 2.46 \\
\hline Index of financial credit inflow openness & 812 & 0.27 & 0.45 & 0.00 & 1.00 \\
\hline Index of financial credit outflow openness & 812 & 0.30 & 0.46 & 0.00 & 1.00 \\
\hline \multicolumn{6}{|l|}{ Macroeconomic control variables } \\
\hline Domestic credit / GDP & 922 & 0.77 & 0.58 & 0.04 & 3.28 \\
\hline Initial Income (Log GDP per capita in 1996) & 922 & 8.16 & 1.51 & 5.03 & 10.50 \\
\hline Inflation (CPI, annual \%) & 922 & 7.45 & 36.12 & -4.48 & 1058.37 \\
\hline Trade share (Exports + Imports / GDP, \%) & 922 & 78.22 & 37.72 & 18.76 & 220.41 \\
\hline Government final consumption expenditure (\% of GDP) & 922 & 15.94 & 5.21 & 4.51 & 30.50 \\
\hline Log secondary school enrollment rate (\%) & 922 & 4.31 & 0.52 & 1.65 & 5.09 \\
\hline
\end{tabular}




\section{Table 2: Correlation Between Different Measures of Financial Openness}

This table shows correlation coefficients between different measures of financial openness. De factor measures of financial openness include foreign assets plus liabilities relative to GDP, foreign bank loans (assets plus liabilities) relative to GDP and the share of foreign banks in the number of all banks ina a given country. The de jure measures comprise the Chinn-Ito index measures de jure financial openness by capital account openness. Values range from -1.84 (financially closed) to 2.46 (financially open). Financial inflow (outflow) openness is constructed from data provided by Klein (2012) and takes on a value of 0 if restrictions are in place ("financially closed") and a value of 1 if no restrictions on financial credit inflows (outflows) are in place (“financially open”).

\begin{tabular}{l|c|c|c|c|c}
\hline \hline & $\begin{array}{c}\text { (Foreign } \\
\text { assets }+ \\
\text { liabilities) } \\
\text { GDP }\end{array}$ & $\begin{array}{c}\text { Foreign bank } \\
\text { loans / GDP }\end{array}$ & $\begin{array}{c}\text { Share of } \\
\text { foreign banks }\end{array}$ & $\begin{array}{c}\text { Chinn-Ito } \\
\text { index }\end{array}$ & $\begin{array}{c}\text { Financial } \\
\text { inflow } \\
\text { openness }\end{array}$ \\
\hline $\begin{array}{l}\text { (Foreign assets + liabilities)/ } \\
\text { GDP }\end{array}$ & 1.00 & & & \\
Foreign bank loans / GDP & 0.74 & 1.00 & 1.00 & 1.00 \\
Share of foreign banks & 0.21 & -0.009 & -0.003 & 0.74 \\
Chinn-Ito index & 0.38 & 0.43 & 0.05 & 0.67 \\
Financial inflow openness & 0.26 & 0.31 & 0.04 & 0.70 \\
Financial outflow openness & 0.21 & 0.22 & & \\
\hline \hline
\end{tabular}




\section{Table 3: Financially Closed and Open Countries}

Panel (a) sorts the countries into financially closed and open depending on the mean of de facto financial openness (FO) measured by the ratio of foreign assets plus liabilities to GDP. The countries are assigned to each category based on the sample mean of FO for each country across the period 1997-2009. Panel (b) sorts the countries into financially closed and open depending on the mean of de jure financial openness measured by the Chinn-Ito index. The countries are assigned to each category based on the sample mean of the Chinn-Ito index for each country across the period 1997-2009.

(a) De facto financial openness (foreign assets plus liabilities / GDP)

\begin{tabular}{|c|c|c|c|c|c|c|c|c|c|c|c|}
\hline \multicolumn{4}{|c|}{ Financially open $(\mathrm{FO}>2.2)$} & \multicolumn{8}{|c|}{ Financially closed $(\mathrm{FO}<2.2)$} \\
\hline Country & Mean & Min & Max & Country & Mean & Min & Max & Country & Mean & Min & Max \\
\hline Austria & 3.7 & 1.5 & 5.9 & Algeria & 0.9 & 0.8 & 1.0 & Lithuania & 1.1 & 0.6 & 1.7 \\
\hline Belgium & 7.5 & 4.2 & 10.2 & Argentina & 1.6 & 1.0 & 3.0 & Malawi & 1.5 & 0.5 & 2.2 \\
\hline Denmark & 3.6 & 1.8 & 4.8 & Australia & 2.0 & 1.2 & 3.0 & Malaysia & 1.9 & 1.5 & 2.4 \\
\hline Finland & 3.5 & 1.4 & 5.4 & Bangladesh & 0.5 & 0.4 & 0.6 & Mali & 1.2 & 0.6 & 1.7 \\
\hline France & 3.9 & 1.8 & 5.8 & Benin & 1.2 & 0.9 & 1.4 & Mauritius & 0.7 & 0.7 & 0.8 \\
\hline Germany & 3.0 & 1.4 & 4.1 & Bolivia & 1.5 & 1.3 & 1.8 & Mexico & 0.8 & 0.7 & 1.0 \\
\hline Hungary & 2.3 & 1.2 & 5.6 & Brazil & 0.9 & 0.8 & 1.0 & Mozambique & 1.7 & 1.4 & 2.2 \\
\hline Ireland & 16.9 & 4.9 & 30.9 & Bulgaria & 1.8 & 1.4 & 2.4 & Nepal & 0.8 & 0.7 & 0.9 \\
\hline Jordan & 2.3 & 1.5 & 3.0 & Cameroon & 0.9 & 0.7 & 1.1 & Nicaragua & 2.1 & 1.5 & 2.6 \\
\hline Kuwait & 2.6 & 2.2 & 3.1 & Canada & 2.0 & 1.7 & 2.2 & Pakistan & 0.7 & 0.6 & 0.8 \\
\hline Netherlands & 6.7 & 3.0 & 9.7 & China & 0.8 & 0.5 & 1.1 & Paraguay & 1.0 & 0.7 & 1.4 \\
\hline Norway & 2.5 & 1.3 & 4.1 & Colombia & 0.8 & 0.7 & 0.9 & Peru & 1.1 & 1.0 & 1.2 \\
\hline Panama & 3.6 & 3.1 & 4.6 & Costa Rica & 1.0 & 0.8 & 1.3 & Philippines & 1.2 & 0.9 & 1.4 \\
\hline Portugal & 3.5 & 1.4 & 5.0 & Croatia & 1.3 & 0.7 & 2.1 & Poland & 1.0 & 0.6 & 1.4 \\
\hline Spain & 2.5 & 1.1 & 3.6 & Czech Republic & 1.4 & 1.0 & 1.8 & Romania & 0.9 & 0.6 & 1.4 \\
\hline Sweden & 3.7 & 2.2 & 5.7 & Dominican Rep. & 0.7 & 0.4 & 1.0 & Russia & 1.4 & 0.8 & 2.2 \\
\hline Switzerland & 9.6 & 5.0 & 13.4 & Egypt, Arab Rep. & 1.0 & 0.8 & 1.3 & Rwanda & 1.2 & 1.0 & 1.4 \\
\hline \multirow[t]{15}{*}{ United Kingdom } & 7.3 & 4.6 & 13.2 & El Salvador & 1.0 & 0.7 & 1.2 & Senegal & 1.2 & 0.8 & 1.4 \\
\hline & & & & Estonia & 2.0 & 0.7 & 3.1 & Slovak Rep. & 1.1 & 0.8 & 1.4 \\
\hline & & & & Georgia & 1.1 & 0.9 & 1.6 & Slovenia & 1.4 & 0.7 & 2.4 \\
\hline & & & & Ghana & 1.3 & 0.5 & 1.8 & South Africa & 1.4 & 0.9 & 1.9 \\
\hline & & & & Greece & 1.7 & 1.0 & 2.8 & Sudan & 1.6 & 1.2 & 1.8 \\
\hline & & & & Guatemala & 0.6 & 0.5 & 0.8 & Thailand & 1.3 & 1.0 & 1.7 \\
\hline & & & & Honduras & 1.2 & 1.0 & 1.3 & Tunisia & 1.4 & 1.1 & 1.6 \\
\hline & & & & India & 0.5 & 0.4 & 0.8 & Turkey & 0.9 & 0.8 & 1.0 \\
\hline & & & & Indonesia & 0.9 & 0.6 & 1.3 & Uganda & 1.0 & 0.7 & 1.3 \\
\hline & & & & Israel & 1.8 & 1.0 & 2.4 & United States & 1.9 & 1.1 & 3.0 \\
\hline & & & & Italy & 2.1 & 1.2 & 2.8 & Uruguay & 1.7 & 1.1 & 2.5 \\
\hline & & & & Japan & 1.4 & 1.0 & 1.9 & Venezuela, RB & 1.3 & 0.9 & 1.9 \\
\hline & & & & Kenya & 0.8 & 0.7 & 0.9 & Zimbabwe & 0.8 & 0.8 & 0.9 \\
\hline & & & & Korea, Rep. & 1.0 & 0.6 & 1.6 & & & & \\
\hline & & & & Latvia & 1.7 & 0.9 & 3.0 & & & & \\
\hline
\end{tabular}


(b) De jure financial openness (Chinn-Ito index)

\begin{tabular}{|c|c|c|c|c|c|c|c|}
\hline \multicolumn{4}{|c|}{ Financially open (Chinn-Ito > 1.0) } & \multicolumn{4}{|c|}{ Financially closed (Chinn-Ito <=1.0) } \\
\hline Country & Mean & Min & Max & Country & Mean & Min & Max \\
\hline Australia & 1.3 & 1.1 & 2.2 & Algeria & -1.2 & -1.2 & -1.2 \\
\hline Austria & 2.5 & 2.5 & 2.5 & Argentina & 0.2 & -1.2 & 2.2 \\
\hline Belgium & 2.2 & 1.7 & 2.5 & Bangladesh & -1.2 & -1.2 & -1.2 \\
\hline Bolivia & 1.3 & 0.9 & 1.4 & Benin & -1.2 & -1.2 & -1.2 \\
\hline Canada & 2.5 & 2.5 & 2.5 & Brazil & -0.0 & -0.1 & 0.2 \\
\hline Costa Rica & 1.1 & 0.4 & 1.2 & Bulgaria & 0.1 & -1.2 & 2.5 \\
\hline Czech Republic & 1.4 & -0.1 & 2.5 & Cameroon & -1.2 & -1.2 & -1.2 \\
\hline Denmark & 2.5 & 2.5 & 2.5 & China & -1.2 & -1.2 & -1.2 \\
\hline Egypt, Arab Rep. & 1.7 & 0.7 & 2.5 & Colombia & -0.5 & -1.2 & 1.1 \\
\hline El Salvador & 2.4 & 1.9 & 2.5 & Croatia & 0.5 & -0.1 & 1.1 \\
\hline Estonia & 2.4 & 1.9 & 2.5 & Dominican Rep. & 0.1 & -1.6 & 1.9 \\
\hline Finland & 2.5 & 2.5 & 2.5 & Ghana & -1.2 & -1.2 & -1.2 \\
\hline France & 2.5 & 2.5 & 2.5 & Honduras & 0.3 & -0.1 & 1.1 \\
\hline Georgia & 1.3 & 0.7 & 1.4 & India & -1.2 & -1.2 & -1.2 \\
\hline Germany & 2.5 & 2.5 & 2.5 & Korea, Rep. & -0.4 & -1.2 & 0.4 \\
\hline Greece & 1.7 & 0.3 & 2.5 & Malawi & -1.3 & -1.9 & -1.2 \\
\hline Guatemala & 2.0 & 1.2 & 2.5 & Malaysia & 0.2 & -0.1 & 1.1 \\
\hline Hungary & 1.4 & -0.1 & 2.5 & Mali & -1.2 & -1.2 & -1.2 \\
\hline Indonesia & 1.3 & 1.1 & 2.2 & Mexico & 1.0 & 0.1 & 1.1 \\
\hline Ireland & 2.5 & 2.5 & 2.5 & Mozambique & -1.2 & -1.2 & -1.2 \\
\hline Israel & 1.7 & -1.2 & 2.5 & Nepal & -1.2 & -1.2 & -1.2 \\
\hline Italy & 2.5 & 2.5 & 2.5 & Pakistan & -1.2 & -1.2 & -1.2 \\
\hline Japan & 2.4 & 2.2 & 2.5 & Philippines & 0.1 & 0.1 & 0.1 \\
\hline Jordan & 2.1 & 0.1 & 2.5 & Poland & -0.4 & -1.2 & 0.1 \\
\hline Kenya & 1.1 & 1.1 & 1.1 & Romania & 0.6 & -1.2 & 2.5 \\
\hline Kuwait & 1.4 & 1.1 & 2.2 & Russia & -0.4 & -1.9 & -0.1 \\
\hline Latvia & 2.3 & 1.9 & 2.5 & Rwanda & -1.2 & -1.2 & -1.2 \\
\hline Lithuania & 2.4 & 1.9 & 2.5 & Senegal & -1.2 & -1.2 & -1.2 \\
\hline Mauritius & 1.7 & 0.2 & 2.5 & Slovak Republic & -0.2 & -1.2 & 1.4 \\
\hline Netherlands & 2.5 & 2.5 & 2.5 & South Africa & -1.2 & -1.2 & -1.2 \\
\hline Nicaragua & 2.5 & 2.5 & 2.5 & Sudan & -0.3 & -0.9 & 0.4 \\
\hline Norway & 2.3 & 1.7 & 2.5 & Thailand & -0.3 & -1.2 & -0.1 \\
\hline Panama & 2.5 & 2.5 & 2.5 & Tunisia & -1.2 & -1.2 & -1.2 \\
\hline Paraguay & 1.1 & -0.9 & 1.4 & Turkey & -1.0 & -1.2 & 0.1 \\
\hline Peru & 2.4 & 1.1 & 2.5 & Venezuela, RB & 0.3 & -1.3 & 2.5 \\
\hline Portugal & 2.4 & 2.2 & 2.5 & Zimbabwe & -1.2 & -1.2 & -1.2 \\
\hline Slovenia & 1.1 & -1.2 & 2.5 & & & & \\
\hline Spain & 2.4 & 1.9 & 2.5 & & & & \\
\hline Sweden & 2.4 & 2.2 & 2.5 & & & & \\
\hline Switzerland & 2.5 & 2.5 & 2.5 & & & & \\
\hline Uganda & 2.2 & 0.2 & 2.5 & & & & \\
\hline United Kingdom & 2.5 & 2.5 & 2.5 & & & & \\
\hline United States & 2.5 & 2.5 & 2.5 & & & & \\
\hline Uruguay & 2.3 & 1.7 & 2.5 & & & & \\
\hline
\end{tabular}




\section{Table 4: Baseline Regressions and Interaction with Financial Openness Measures}

The dependent variable is the annual growth rate of real GDP per capita. Time fixed effects are included in all regressions but are not reported. The Banking Granular Residual is a measure for idiosyncratic shocks at the bank-level and is computed as described in the main text. ***, **, * = significant at the $1 \%$, $5 \%$, $10 \%$ level. "FO" is financial assets plus liabilities to GDP while "FO (banks)" stands for foreign bank loans (assets and liabilities) to GDP.

(a) GDP growth and de facto financial openness

\begin{tabular}{|c|c|c|c|c|c|c|c|}
\hline & $\begin{array}{c}\text { (1) } \\
\text { Baseline }\end{array}$ & $\begin{array}{c}\text { (2) } \\
\text { Financial } \\
\text { openness }\end{array}$ & $\begin{array}{c}\text { (3) } \\
\text { Financial } \\
\text { openness }\end{array}$ & $\begin{array}{c}\text { (4) } \\
\text { Financial } \\
\text { openness } \\
\text { (banks) }\end{array}$ & $\begin{array}{c}\text { (5) } \\
\text { Financial } \\
\text { openness } \\
\text { (banks) }\end{array}$ & $\begin{array}{c}\text { (6) } \\
\text { Share of } \\
\text { foreign banks }\end{array}$ & $\begin{array}{c}\text { (7) } \\
\text { Share of } \\
\text { foreign banks }\end{array}$ \\
\hline Banking Granular Residual (assets) & $\begin{array}{c}0.042^{* *} \\
(2.439)\end{array}$ & $\begin{array}{c}0.041^{* *} \\
(2.359)\end{array}$ & $\begin{array}{c}0.062 * * * \\
(2.732)\end{array}$ & $\begin{array}{c}0.041^{*} \\
(1.741)\end{array}$ & $\begin{array}{c}0.043 \\
(1.462)\end{array}$ & $\begin{array}{l}0.042^{*} \\
(1.918)\end{array}$ & $\begin{array}{c}0.077^{* *} \\
(2.339)\end{array}$ \\
\hline Domestic credit / GDP & $\begin{array}{c}-0.020 * * * \\
(-2.970)\end{array}$ & $\begin{array}{c}-0.017 * * \\
(-2.561)\end{array}$ & $\begin{array}{c}-0.017 * * \\
(-2.560)\end{array}$ & $\begin{array}{c}-0.019 * * * \\
(-2.609)\end{array}$ & $\begin{array}{c}-0.019 * * * \\
(-2.597)\end{array}$ & $\begin{array}{c}-0.016^{* *} \\
(-2.244)\end{array}$ & $\begin{array}{c}-0.016^{* *} \\
(-2.228)\end{array}$ \\
\hline Inflation, consumer prices (annual \%) & $\begin{array}{c}-0.000 * * * \\
(-3.412)\end{array}$ & $\begin{array}{c}-0.000 * * * \\
(-3.399)\end{array}$ & $\begin{array}{c}-0.000 * * * \\
(-3.450)\end{array}$ & $\begin{array}{c}-0.001^{* * *} \\
(-3.382)\end{array}$ & $\begin{array}{c}-0.001 * * * \\
(-3.323)\end{array}$ & $\begin{array}{c}-0.000 * * * \\
(-5.807)\end{array}$ & $\begin{array}{c}-0.000 * * * \\
(-5.759)\end{array}$ \\
\hline Initial income (Log real GDP per capita in 1996) & $\begin{array}{c}-0.001 \\
(-0.248)\end{array}$ & $\begin{array}{c}0.001 \\
(0.348)\end{array}$ & $\begin{array}{c}0.001 \\
(0.265)\end{array}$ & $\begin{array}{c}-0.001 \\
(-0.168)\end{array}$ & $\begin{array}{c}-0.001 \\
(-0.173)\end{array}$ & $\begin{array}{c}-0.004 \\
(-1.025)\end{array}$ & $\begin{array}{c}-0.004 \\
(-1.037)\end{array}$ \\
\hline Secondary school enrollment & $\begin{array}{c}0.013^{* *} \\
(1.996)\end{array}$ & $\begin{array}{c}0.009 \\
(1.397)\end{array}$ & $\begin{array}{c}0.009 \\
(1.468)\end{array}$ & $\begin{array}{c}0.018 * * * \\
(2.717)\end{array}$ & $\begin{array}{c}0.018 * * * \\
(2.715)\end{array}$ & $\begin{array}{c}0.023 * * * \\
(3.072)\end{array}$ & $\begin{array}{c}0.022 * * * \\
(3.040)\end{array}$ \\
\hline Trade (\% of GDP) & $\begin{array}{c}0.000 * * * \\
(2.974)\end{array}$ & $\begin{array}{c}0.000 * * * \\
(3.387)\end{array}$ & $\begin{array}{c}0.000 * * * \\
(3.345)\end{array}$ & $\begin{array}{c}0.000 * * * \\
(3.251)\end{array}$ & $\begin{array}{c}0.000 * * * \\
(3.272)\end{array}$ & $\begin{array}{c}0.000 * * * \\
(2.822)\end{array}$ & $\begin{array}{c}0.000 * * * \\
(2.791)\end{array}$ \\
\hline General government consumption (\% of GDP) & $\begin{array}{c}-0.001^{* * *} \\
(-2.638)\end{array}$ & $\begin{array}{c}-0.001^{* *} \\
(-2.369)\end{array}$ & $\begin{array}{c}-0.001 * * \\
(-2.404)\end{array}$ & $\begin{array}{c}-0.001 * * \\
(-2.365)\end{array}$ & $\begin{array}{c}-0.001^{* *} \\
(-2.339)\end{array}$ & $\begin{array}{c}-0.001^{* * *} \\
(-3.533)\end{array}$ & $\begin{array}{c}-0.001^{* * *} \\
(-3.372)\end{array}$ \\
\hline $\begin{array}{l}\text { (Foreign assets }+ \text { liabilities) / GDP } \\
\text { (Foreign assets }+ \text { liabilities) / GDP * BGR (assets) }\end{array}$ & & $\begin{array}{c}-0.003 * * * \\
(-4.135)\end{array}$ & $\begin{array}{c}-0.002 * * * \\
(-3.167) \\
-0.009 * * * \\
(-2.577)\end{array}$ & & & & \\
\hline Foreign bank loans / GDP & & & & $\begin{array}{c}-0.016 * * * \\
(-3.800)\end{array}$ & $\begin{array}{c}-0.016 * * * \\
(-3.801)\end{array}$ & & \\
\hline Foreign bank loans / GDP * BGR (assets) & & & & & $\begin{array}{c}-0.007 \\
(-0.170)\end{array}$ & & \\
\hline Share of foreign banks & & & & & & $\begin{array}{c}-0.000 \\
(-1.337)\end{array}$ & $\begin{array}{c}-0.000 \\
(-0.891)\end{array}$ \\
\hline Share of foreign banks * BGR (assets) & & & & & & & $\begin{array}{c}-0.004 \\
(-1.625)\end{array}$ \\
\hline Observations & 922 & 922 & 922 & 562 & 562 & 703 & 703 \\
\hline Number of countries & 80 & 80 & 80 & 56 & 56 & 61 & 61 \\
\hline$R^{2}$ & 0.374 & 0.392 & 0.395 & 0.503 & 0.503 & 0.382 & 0.388 \\
\hline
\end{tabular}


(b) GDP growth and de jure financial openness

\begin{tabular}{|c|c|c|c|c|c|c|}
\hline & $\begin{array}{c}\text { (8) } \\
\text { Chinn-Ito } \\
\text { index }\end{array}$ & $\begin{array}{c}\text { (9) } \\
\text { Chinn-Ito } \\
\text { index }\end{array}$ & $\begin{array}{c}(10) \\
\text { Financial } \\
\text { inflow } \\
\text { openness }\end{array}$ & $\begin{array}{c}(11) \\
\text { Financial } \\
\text { inflow } \\
\text { openness }\end{array}$ & $\begin{array}{c}(12) \\
\text { Financial } \\
\text { outflow } \\
\text { openness }\end{array}$ & $\begin{array}{c}(13) \\
\text { Financial } \\
\text { outflow } \\
\text { openness }\end{array}$ \\
\hline Banking Granular Residual (assets) & $\begin{array}{l}0.043^{* *} \\
(-2.481)\end{array}$ & $\begin{array}{c}0.032 \\
(-1.434)\end{array}$ & $\begin{array}{c}0.049 * * * \\
(-2.750)\end{array}$ & $\begin{array}{c}0.058 \\
(-1.442)\end{array}$ & $\begin{array}{c}0.049 * * * \\
(-2.698)\end{array}$ & $\begin{array}{c}0.066 * \\
(-1.836)\end{array}$ \\
\hline Domestic credit / GDP & $\begin{array}{c}-0.020 * * * \\
(-2.972)\end{array}$ & $\begin{array}{c}-0.019 * * * \\
(-2.907)\end{array}$ & $\begin{array}{c}-0.018 * * * \\
(-2.658)\end{array}$ & $\begin{array}{c}-0.017 * * * \\
(-2.608)\end{array}$ & $\begin{array}{c}-0.017 * * * \\
(-2.616)\end{array}$ & $\begin{array}{c}-0.017 * * * \\
(-2.601)\end{array}$ \\
\hline Inflation, consumer prices (annual \%) & $\begin{array}{c}-0.000 * * * \\
(-3.420)\end{array}$ & $\begin{array}{c}-0.000 * * * \\
(-3.320)\end{array}$ & $\begin{array}{c}-0.000 * * * \\
(-3.524)\end{array}$ & $\begin{array}{c}-0.000 * * * \\
(-3.538)\end{array}$ & $\begin{array}{c}-0.000 * * * \\
(-3.533)\end{array}$ & $\begin{array}{c}-0.000 * * * \\
(-3.563)\end{array}$ \\
\hline log real GDP/capita in 1996 & $\begin{array}{c}-0.001 \\
(-0.173)\end{array}$ & $\begin{array}{c}-0.001 \\
(-0.240)\end{array}$ & $\begin{array}{c}-0.003 \\
(-0.822)\end{array}$ & $\begin{array}{c}-0.003 \\
(-0.898)\end{array}$ & $\begin{array}{c}-0.003 \\
(-0.982)\end{array}$ & $\begin{array}{c}-0.004 \\
(-1.030)\end{array}$ \\
\hline Schooling & $\begin{array}{l}0.013^{* *} \\
(-1.988)\end{array}$ & $\begin{array}{l}0.013^{* *} \\
(-1.965)\end{array}$ & $\begin{array}{c}0.024 * * * \\
(-2.594)\end{array}$ & $\begin{array}{c}0.024 * * * \\
(-2.613)\end{array}$ & $\begin{array}{c}0.025^{* * *} \\
(-2.804)\end{array}$ & $\begin{array}{c}0.025^{* * *} \\
(-2.819)\end{array}$ \\
\hline Trade (\% of GDP) & $\begin{array}{c}0.000 * * * \\
(-3.044)\end{array}$ & $\begin{array}{c}0.000 * * * \\
(-3.036)\end{array}$ & $\begin{array}{l}0.000 * * \\
(-2.422)\end{array}$ & $\begin{array}{l}0.000 * * \\
(-2.370)\end{array}$ & $\begin{array}{l}0.000 * * \\
(-2.408)\end{array}$ & $\begin{array}{l}0.000 * * \\
(-2.351)\end{array}$ \\
\hline General government consumption (\% of GDP) & $\begin{array}{c}-0.001 * * * \\
(-2.641)\end{array}$ & $\begin{array}{c}-0.001^{* *} \\
(-2.543)\end{array}$ & $\begin{array}{c}-0.001 * * * \\
(-3.071)\end{array}$ & $\begin{array}{c}-0.001 * * * \\
(-2.975)\end{array}$ & $\begin{array}{c}-0.001^{* * *} \\
(-3.145)\end{array}$ & $\begin{array}{c}-0.001 * * * \\
(-3.129)\end{array}$ \\
\hline Chinn-Ito index of capital controls & $\begin{array}{c}-0.000 \\
(-0.321)\end{array}$ & $\begin{array}{c}-0.000 \\
(-0.307)\end{array}$ & & & & \\
\hline Chinn-Ito index * BGR (assets) & & $\begin{array}{c}0.011 \\
(0.998)\end{array}$ & & & & \\
\hline Financial inflow openness & & & $\begin{array}{c}-0.003 \\
(-0.574)\end{array}$ & $\begin{array}{c}-0.003 \\
(-0.600)\end{array}$ & & \\
\hline Financial inflow openness * BGR (assets) & & & & $\begin{array}{c}-0.014 \\
(-0.306)\end{array}$ & & \\
\hline Financial outflow openness & & & & & $\begin{array}{c}-0.003 \\
(-0.821)\end{array}$ & $\begin{array}{c}-0.003 \\
(-0.853)\end{array}$ \\
\hline Financial outflow openness * BGR (assets) & & & & & & $\begin{array}{c}-0.027 \\
(-0.657)\end{array}$ \\
\hline Observations & 922 & 922 & 812 & 812 & 812 & 812 \\
\hline Number of countries & 80 & 80 & 68 & 68 & 68 & 68 \\
\hline$R^{2}$ & 0.374 & 0.372 & 0.404 & 0.403 & 0.403 & 0.403 \\
\hline
\end{tabular}


(c) GDP growth and de jure financial openness: Countries with changes in de jure openness only

This table presents regression results for the sample of countries which have experienced changes in the three different measures of de jure financial openness, the Chinn-Ito index, and restrictions on in- and outflows of financial credit. Countries which have had the same index value throughout the sample period 19962009 are not included in columns (2) - (7).

\begin{tabular}{|c|c|c|c|c|c|c|c|}
\hline & $\begin{array}{c}(1) \\
\text { Baseline }\end{array}$ & $\begin{array}{c}(2) \\
\text { Chinn-Ito } \\
\text { index }\end{array}$ & $\begin{array}{c}\text { (3) } \\
\text { Chinn-Ito } \\
\text { index }\end{array}$ & $\begin{array}{c}(4) \\
\text { Financial } \\
\text { inflow } \\
\text { openness }\end{array}$ & $\begin{array}{c}\text { (5) } \\
\text { Financial } \\
\text { inflow } \\
\text { openness }\end{array}$ & $\begin{array}{c}(6) \\
\text { Financial } \\
\text { outflow } \\
\text { openness }\end{array}$ & $\begin{array}{c}\text { (7) } \\
\text { Financial } \\
\text { outflow } \\
\text { openness }\end{array}$ \\
\hline Banking Granular Residual (assets) & $\begin{array}{c}0.042 * * \\
(2.439)\end{array}$ & $\begin{array}{c}0.049 * * \\
(1.974)\end{array}$ & $\begin{array}{c}0.044 \\
(1.302)\end{array}$ & $\begin{array}{c}0.069^{*} \\
(-1.869)\end{array}$ & $\begin{array}{c}0.086^{*} \\
(-1.928)\end{array}$ & $\begin{array}{c}0.090^{*} \\
(-1.914)\end{array}$ & $\begin{array}{c}0.080^{*} \\
(-1.656)\end{array}$ \\
\hline Domestic credit / GDP & $\begin{array}{c}-0.020 * * * \\
(-2.970)\end{array}$ & $\begin{array}{c}-0.021 * * \\
(-2.312)\end{array}$ & $\begin{array}{c}-0.021^{* *} \\
(-2.319)\end{array}$ & $\begin{array}{c}-0.035^{* *} \\
(-2.321)\end{array}$ & $\begin{array}{c}-0.035^{* *} \\
(-2.314)\end{array}$ & $\begin{array}{c}0.003 \\
(0.201)\end{array}$ & $\begin{array}{c}0.003 \\
(0.217)\end{array}$ \\
\hline Inflation, consumer prices (annual \%) & $\begin{array}{c}-0.000 * * * \\
(-3.412)\end{array}$ & $\begin{array}{c}-0.000 * * * \\
(-3.612)\end{array}$ & $\begin{array}{c}-0.000 * * * \\
(-3.579)\end{array}$ & $\begin{array}{c}-0.000 * * * \\
(-4.532)\end{array}$ & $\begin{array}{c}-0.000 * * * \\
(-4.321)\end{array}$ & $\begin{array}{c}-0.000 * * * \\
(-2.701)\end{array}$ & $\begin{array}{c}-0.000 * * * \\
(-2.671)\end{array}$ \\
\hline log real GDP/capita in 1996 & $\begin{array}{c}-0.001 \\
(-0.248)\end{array}$ & $\begin{array}{c}-0.002 \\
(-0.822)\end{array}$ & $\begin{array}{c}-0.002 \\
(-0.733)\end{array}$ & $\begin{array}{c}-0.005 \\
(-0.760)\end{array}$ & $\begin{array}{c}-0.006 \\
(-0.757)\end{array}$ & $\begin{array}{c}-0.015^{* * * *} \\
(-2.650)\end{array}$ & $\begin{array}{c}-0.015 * * * \\
(-2.678)\end{array}$ \\
\hline Schooling & $\begin{array}{c}0.013^{* *} \\
(1.996)\end{array}$ & $\begin{array}{l}0.020^{* *} \\
(2.413)\end{array}$ & $\begin{array}{l}0.020^{* *} \\
(2.382)\end{array}$ & $\begin{array}{c}0.051 \\
(-1.549)\end{array}$ & $\begin{array}{c}0.053 \\
(-1.533)\end{array}$ & $\begin{array}{c}-0.002 \\
(-0.155)\end{array}$ & $\begin{array}{c}-0.002 \\
(-0.134)\end{array}$ \\
\hline Trade (\% of GDP) & $\begin{array}{c}0.000^{* * *} \\
(2.974)\end{array}$ & $\begin{array}{l}0.000^{* *} \\
(2.089)\end{array}$ & $\begin{array}{l}0.000^{* *} \\
(2.107)\end{array}$ & $\begin{array}{l}0.000^{* *} \\
(-2.230)\end{array}$ & $\begin{array}{l}0.000^{* *} \\
(-2.445)\end{array}$ & $\begin{array}{c}-0.000 \\
(-0.971)\end{array}$ & $\begin{array}{c}-0.000 \\
(-0.983)\end{array}$ \\
\hline General government consumption (\% of GDP) & $\begin{array}{c}-0.001 * * * \\
(-2.638)\end{array}$ & $\begin{array}{c}-0.000 \\
(-1.246)\end{array}$ & $\begin{array}{c}-0.001 \\
(-1.334)\end{array}$ & $\begin{array}{c}-0.002 \\
(-1.546)\end{array}$ & $\begin{array}{c}-0.002 \\
(-1.557)\end{array}$ & $\begin{array}{c}0.001 \\
(0.902)\end{array}$ & $\begin{array}{c}0.001 \\
(0.896)\end{array}$ \\
\hline Chinn-Ito index of capital controls & & $\begin{array}{c}0.001 \\
(0.374)\end{array}$ & $\begin{array}{c}0.001 \\
(0.381)\end{array}$ & & & & \\
\hline Chinn-Ito index * BGR (assets) & & & $\begin{array}{c}0.007 \\
(0.303)\end{array}$ & & & & \\
\hline Financial inflow openness & & & & $\begin{array}{c}-0.004 \\
(-0.422)\end{array}$ & $\begin{array}{c}-0.005 \\
(-0.545)\end{array}$ & & \\
\hline Financial inflow openness * BGR (assets) & & & & & $\begin{array}{c}-0.073 \\
(-1.010)\end{array}$ & & \\
\hline Financial outflow openness & & & & & & $\begin{array}{c}-0.001 \\
(-0.279)\end{array}$ & $\begin{array}{c}-0.001 \\
(-0.302)\end{array}$ \\
\hline Financial outflow openness * BGR (assets) & & & & & & & $\begin{array}{c}0.055 \\
(0.445)\end{array}$ \\
\hline Observations & 922 & 546 & 546 & 182 & 182 & 183 & 183 \\
\hline Number of countries & 80 & 46 & 46 & 15 & 15 & 14 & 14 \\
\hline$R^{2}$ & 0.374 & 0.385 & 0.386 & 0.396 & 0.399 & 0.343 & 0.346 \\
\hline
\end{tabular}




\section{Table 5: Panel-Threshold Regressions}

The dependent variable is growth of real GDP per capita. Columns (1) - (3) show regression results for different measures of de facto financial openness as a threshold variable. In column (4) the Chinn-Ito index as a de jure measure of financial openness is used as a threshold variable. Time-fixed effects are included in all regressions. Standard errors are given in parentheses. Grey markers indicate statistical significance. "FO" is financial assets plus liabilities to GDP while "FO (banks)” stands for foreign bank loans (assets and liabilities) to GDP.

\begin{tabular}{|c|c|c|c|c|}
\hline & $\begin{array}{l}(1) \\
\text { FO }\end{array}$ & $\begin{array}{c}(2) \\
\text { FO (banks) }\end{array}$ & $\begin{array}{c}\text { (3) } \\
\text { Share of foreign banks }\end{array}$ & $\begin{array}{c}\text { (4) } \\
\text { Chinn-Ito }\end{array}$ \\
\hline \multicolumn{5}{|l|}{ Threshold estimates } \\
\hline Threshold $\gamma$ & 2.84 & 0.81 & 0.09 & -0.89 \\
\hline \multicolumn{5}{|l|}{$\begin{array}{l}\text { 95\% confidence interval } \\
\text { Impact of the BGR (assets) }\end{array}$} \\
\hline \multirow[t]{2}{*}{$\beta_{1}($ if $\mathrm{TH}<\gamma)$} & 0.046 & 0.030 & 0.096 & -0.008 \\
\hline & $(0.014)$ & $(0.016)$ & $(0.03)$ & $(0.03)$ \\
\hline \multirow[t]{2}{*}{$\beta_{2}($ if $\mathrm{TH}>=\gamma)$} & 0.019 & -0.01 & -0.004 & 0.05 \\
\hline & $(0.030)$ & $(0.05)$ & $(0.018)$ & $(0.01)$ \\
\hline \multicolumn{5}{|l|}{ Control variables } \\
\hline \multirow[t]{2}{*}{ Domestic credit / GDP } & -0.043 & -0.056 & -0.059 & -0.049 \\
\hline & $(0.005)$ & $(0.007)$ & $(0.007)$ & $(0.005)$ \\
\hline \multirow[t]{2}{*}{ Inflation, consumer prices (annual \%) } & -0.000 & -0.001 & -0.001 & -0.000 \\
\hline & $(0.000)$ & $(0.000)$ & $(0.000)$ & $(0.000)$ \\
\hline \multirow[t]{2}{*}{ Secondary school enrollment } & 0.006 & 0.012 & 0.021 & 0.011 \\
\hline & $(0.008)$ & $(0.014)$ & $(0.013)$ & $(0.008)$ \\
\hline \multirow[t]{2}{*}{ Trade (\% of GDP) } & 0.001 & 0.001 & 0.001 & 0.001 \\
\hline & $(0.000)$ & $(0.000)$ & $(0.000)$ & $(0.000)$ \\
\hline \multirow[t]{2}{*}{ Government expenditures (\% of GDP) } & -0.002 & -0.004 & -0.003 & -0.002 \\
\hline & $(0.001)$ & $(0.001)$ & $(0.001)$ & $(0.001)$ \\
\hline \multirow[t]{2}{*}{ Regime-specific constant } & 0.023 & 0.024 & -0.017 & -0.01 \\
\hline & $(0.005)$ & $(0.007)$ & $(0.006)$ & $(0.004)$ \\
\hline Observations & 982 & 447 & 447 & 982 \\
\hline Number of countries & 79 & 39 & 39 & 79 \\
\hline
\end{tabular}




\section{Table 6: Sample Splits with Regard to Time}

The dependent variable is the annual growth rate of real GDP per capita. Time fixed effects are included in all regressions but are not reported. BGR is the banking granular residual based on banks' assets. $* * *, * *, *=$ significant at the $1 \%, 5 \%, 10 \%$ level.

\begin{tabular}{|c|c|c|c|c|c|c|c|c|}
\hline & $\begin{array}{c}(1) \\
\text { Full sample }\end{array}$ & $\begin{array}{c}(2) \\
1996-2000 \\
\end{array}$ & $\begin{array}{c}(3) \\
2001-2005 \\
\end{array}$ & $\begin{array}{c}(4) \\
2006-2009 \\
\end{array}$ & $\begin{array}{c}(5) \\
1996-1999 \\
\end{array}$ & $\begin{array}{c}(6) \\
2000-2009 \\
\end{array}$ & $\begin{array}{c}(7) \\
1996-2006 \\
\end{array}$ & $\begin{array}{c}(8) \\
2007-2009 \\
\end{array}$ \\
\hline Banking Granular Residual (assets) & $\begin{array}{c}0.062 * * * \\
(2.732)\end{array}$ & $\begin{array}{c}0.019 \\
(0.524)\end{array}$ & $\begin{array}{l}-0.013 \\
(0.400)\end{array}$ & $\begin{array}{c}0.114^{* *} \\
(2.209)\end{array}$ & $\begin{array}{c}0.014 \\
(0.297)\end{array}$ & $\begin{array}{c}0.062^{* *} \\
(2.528)\end{array}$ & $\begin{array}{c}0.031 \\
(1.086)\end{array}$ & $\begin{array}{l}0.104 * \\
(1.915)\end{array}$ \\
\hline Domestic credit / GDP & $\begin{array}{c}-0.017 * * \\
(-2.560)\end{array}$ & $\begin{array}{l}-0.015^{*} \\
(-1.791)\end{array}$ & $\begin{array}{c}-0.014 * * \\
(-2.079)\end{array}$ & $\begin{array}{c}-0.002 \\
(-0.241)\end{array}$ & $\begin{array}{l}-0.017^{*} \\
(-1.825)\end{array}$ & $\begin{array}{c}-0.016^{* *} \\
(-2.295)\end{array}$ & $\begin{array}{c}-0.016^{* *} \\
(-2.267)\end{array}$ & $\begin{array}{c}0.000 \\
(0.030)\end{array}$ \\
\hline Inflation, consumer prices (annual \%) & $\begin{array}{c}-0.000 * * * \\
(-3.450)\end{array}$ & $\begin{array}{c}-0.000 * * * \\
(-4.338)\end{array}$ & $\begin{array}{c}-0.001^{* * *} \\
(-3.937)\end{array}$ & $\begin{array}{l}0.001^{*} \\
(-1.704)\end{array}$ & $\begin{array}{c}-0.000^{* * *} \\
(-3.964)\end{array}$ & $\begin{array}{c}-0.001^{* *} \\
(-2.445)\end{array}$ & $\begin{array}{c}-0.000^{* * *} \\
(-3.247)\end{array}$ & $\begin{array}{c}0.001 \\
(-1.637)\end{array}$ \\
\hline Initial income (Log real GDP per capita in 1996) & $\begin{array}{c}0.001 \\
(0.265)\end{array}$ & $\begin{array}{c}0.002 \\
(0.581)\end{array}$ & $\begin{array}{c}-0.001 \\
(-0.178)\end{array}$ & $\begin{array}{c}-0.008 \\
(-1.509)\end{array}$ & $\begin{array}{c}0.002 \\
(0.352)\end{array}$ & $\begin{array}{c}-0.002 \\
(-0.424)\end{array}$ & $\begin{array}{c}0.003 \\
(0.807)\end{array}$ & $\begin{array}{c}-0.008 \\
(-1.494)\end{array}$ \\
\hline Secondary school enrollment & $\begin{array}{c}0.009 \\
(-1.468)\end{array}$ & $\begin{array}{c}0.005 \\
(0.876)\end{array}$ & $\begin{array}{c}0.008 \\
(0.708)\end{array}$ & $\begin{array}{l}0.028^{* *} \\
(-2.100)\end{array}$ & $\begin{array}{c}0.003 \\
(0.456)\end{array}$ & $\begin{array}{c}0.016^{*} \\
(-1.831)\end{array}$ & $\begin{array}{c}0.004 \\
(0.613)\end{array}$ & $\begin{array}{c}0.026^{*} \\
(-1.886)\end{array}$ \\
\hline Trade (\% of GDP) & $\begin{array}{c}0.000^{* * *} \\
(-3.345)\end{array}$ & $\begin{array}{c}0.000 \\
(-1.383)\end{array}$ & $\begin{array}{c}0.000^{* * *} \\
(-2.968)\end{array}$ & $\begin{array}{c}0.000 \\
(-1.343)\end{array}$ & $\begin{array}{c}0.000 \\
(0.647)\end{array}$ & $\begin{array}{c}0.000 * * * \\
(-3.875)\end{array}$ & $\begin{array}{c}0.000 * * * \\
(-3.240)\end{array}$ & $\begin{array}{c}0.000 \\
(0.745)\end{array}$ \\
\hline General government consumption (\% of GDP) & $\begin{array}{c}-0.001 * * \\
(-2.404)\end{array}$ & $\begin{array}{c}-0.000 \\
(-0.222)\end{array}$ & $\begin{array}{c}-0.001^{* *} \\
(-2.102)\end{array}$ & $\begin{array}{c}-0.002 * * * \\
(-2.824)\end{array}$ & $\begin{array}{c}-0.000 \\
(-0.165)\end{array}$ & $\begin{array}{c}-0.001^{* * *} \\
(-3.083)\end{array}$ & $\begin{array}{c}-0.001 \\
(-1.570)\end{array}$ & $\begin{array}{c}-0.002^{* * *} \\
(-3.321)\end{array}$ \\
\hline (Foreign assets + liabilities) / GDP & $\begin{array}{c}-0.002^{* * *} \\
(-3.167)\end{array}$ & $\begin{array}{c}0.002 \\
(-1.203)\end{array}$ & $\begin{array}{c}-0.002 * * \\
(-2.053)\end{array}$ & $\begin{array}{c}-0.001 * * \\
(-1.979)\end{array}$ & $\begin{array}{l}0.003^{*} \\
(-1.921)\end{array}$ & $\begin{array}{c}-0.002 * * * \\
(-2.689)\end{array}$ & $\begin{array}{c}-0.002 * * * \\
(-2.949)\end{array}$ & $\begin{array}{c}-0.000 \\
(-0.969)\end{array}$ \\
\hline (Foreign assets + liabilities) / GDP * BGR (asset) & $\begin{array}{c}-0.009 * * * \\
(-2.577)\end{array}$ & $\begin{array}{c}0.010 \\
(0.940)\end{array}$ & $\begin{array}{c}0.003 \\
(0.356)\end{array}$ & $\begin{array}{c}-0.016^{* * *} \\
(-3.045)\end{array}$ & $\begin{array}{c}0.018 \\
(-1.539)\end{array}$ & $\begin{array}{c}-0.011^{* * *} \\
(-2.747)\end{array}$ & $\begin{array}{c}-0.002 \\
(-0.230)\end{array}$ & $\begin{array}{c}-0.016^{* *} \\
(-2.376)\end{array}$ \\
\hline Observations & 922 & 304 & 358 & 260 & 232 & 690 & 734 & 188 \\
\hline Number of countries & 80 & 77 & 78 & 74 & 76 & 79 & 80 & 71 \\
\hline$R^{2}$ & 0.395 & 0.0771 & 0.312 & 0.675 & 0.0685 & 0.473 & 0.223 & 0.689 \\
\hline
\end{tabular}


Table 7: Instrumental Variables Regressions

This Table presents instrumental variable regressions. Domestic credit to GDP, log GDP per capita, inflation, school enrollment, the trade share, government expenditures relative to GDP and the financial openness measures are instrumented using their own (third) lags as instruments as well as generated instruments using Lewbel's (2012) method. "FO” is financial assets plus liabilities to GDP while "FO (banks)” stands for foreign bank loans (assets and liabilities) to GDP.

\begin{tabular}{|c|c|c|c|c|c|c|}
\hline & $\begin{array}{c}1) \\
\text { Financial } \\
\text { openness }\end{array}$ & $\begin{array}{c}(2) \\
\text { Fin. openness } \\
\text { (banks) }\end{array}$ & $\begin{array}{c}\text { (3) } \\
\text { Share of foreign } \\
\text { banks }\end{array}$ & $\begin{array}{c}\text { (4) } \\
\text { Chinn-Ito index }\end{array}$ & $\begin{array}{c}5) \\
\text { Fin. inflow } \\
\text { openness }\end{array}$ & $\begin{array}{c}(6) \\
\text { Fin. outflow } \\
\text { openness }\end{array}$ \\
\hline Banking Granular Residual (assets) & $\begin{array}{l}0.031^{* *} \\
(-2.159)\end{array}$ & $\begin{array}{c}0.028 \\
(-1.548)\end{array}$ & $\begin{array}{l}0.030^{* *} \\
(-2.098)\end{array}$ & $\begin{array}{c}0.023 \\
(-1.549)\end{array}$ & $\begin{array}{c}0.045^{* * *} \\
(-2.751)\end{array}$ & $\begin{array}{c}0.043^{* * *} \\
(-2.725)\end{array}$ \\
\hline Domestic credit / GDP & $\begin{array}{c}-0.003 \\
(-1.173)\end{array}$ & $\begin{array}{c}-0.008 * * \\
(-2.235)\end{array}$ & $\begin{array}{l}-0.004 \\
(-1.009)\end{array}$ & $\begin{array}{l}-0.006 \\
(-1.558)\end{array}$ & $\begin{array}{l}-0.006^{*} \\
(-1.721)\end{array}$ & $\begin{array}{c}-0.004 \\
(-1.180)\end{array}$ \\
\hline Inflation, consumer prices (annual \%) & $\begin{array}{c}0.000 \\
(-1.193)\end{array}$ & $\begin{array}{c}0.000 * * * \\
(-3.280)\end{array}$ & $\begin{array}{c}0.000 \\
(-1.186)\end{array}$ & $\begin{array}{c}-0.000 \\
(-0.090)\end{array}$ & $\begin{array}{c}0.000 \\
(0.957)\end{array}$ & $\begin{array}{c}0.00 *^{*} \\
(-1.718)\end{array}$ \\
\hline Secondary school enrollment & $\begin{array}{c}0.027 * * * \\
(-4.095)\end{array}$ & $\begin{array}{c}0.023 * * * \\
(-3.316)\end{array}$ & $\begin{array}{c}0.028 * * * \\
(-4.016)\end{array}$ & $\begin{array}{c}0.029 * * * \\
(-3.922)\end{array}$ & $\begin{array}{c}0.032 * * * \\
(-3.367)\end{array}$ & $\begin{array}{c}0.034 * * * \\
(-3.387)\end{array}$ \\
\hline Trade (\% of GDP) & $\begin{array}{c}0.000 * \\
(-1.932)\end{array}$ & $\begin{array}{l}0.000 * * \\
(-2.088)\end{array}$ & $\begin{array}{c}0.000 \\
(-1.201)\end{array}$ & $\begin{array}{l}0.000 * * \\
(-2.028)\end{array}$ & $\begin{array}{c}0.000 \\
(0.899)\end{array}$ & $\begin{array}{c}0.000 \\
(0.897)\end{array}$ \\
\hline General government consumption (\% of GDP) & $\begin{array}{c}-0.000 \\
(-0.189)\end{array}$ & $\begin{array}{c}0.000 \\
(0.523)\end{array}$ & $\begin{array}{c}-0.001 \\
(-1.084)\end{array}$ & $\begin{array}{c}-0.000 \\
(-0.266)\end{array}$ & $\begin{array}{c}0.000 \\
(0.023)\end{array}$ & $\begin{array}{c}-0.000 \\
(-0.287)\end{array}$ \\
\hline Initial income (Log real GDP per capita in 1996) & $\begin{array}{c}-0.010 * * * \\
(-4.872)\end{array}$ & $\begin{array}{c}-0.008 * * * \\
(-3.769)\end{array}$ & $\begin{array}{c}-0.010 * * * \\
(-5.127)\end{array}$ & $\begin{array}{c}-0.008 * * * \\
(-3.805)\end{array}$ & $\begin{array}{c}-0.010 * * * \\
(-4.576)\end{array}$ & $\begin{array}{c}-0.011^{* * * *} \\
(-5.292)\end{array}$ \\
\hline (Foreign assets + liabilities) / GDP & $\begin{array}{c}-0.001 * * * \\
(-4.810)\end{array}$ & & & & & \\
\hline Foreign bank loans / GDP & & $\begin{array}{c}-0.011 * * * \\
(-4.466)\end{array}$ & & & & \\
\hline Share of foreign banks & & & $\begin{array}{c}-0.007 \\
(-1.164)\end{array}$ & & & \\
\hline Chinn-Ito index of capital controls & & & & $\begin{array}{c}-0.005 * * * \\
(-3.148)\end{array}$ & & \\
\hline Financial inflow openness & & & & & $\begin{array}{c}-0.010 * * \\
(-2.547)\end{array}$ & \\
\hline Financial outflow openness & & & & & & $\begin{array}{c}-0.011 * * * \\
(-2.751)\end{array}$ \\
\hline Observations & 623 & 372 & 477 & 623 & 564 & 564 \\
\hline $\mathrm{R}^{2}$ & 0.114 & 0.228 & 0.159 & 0.113 & 0.151 & 0.150 \\
\hline Number of countries & 78 & 51 & 59 & 78 & 68 & 68 \\
\hline p-value of Hansen j-Statistic & 0.345 & 0.551 & 0.414 & 0.503 & 0.791 & 0.324 \\
\hline Hansen j-Statistic & 13.34 & 10.75 & 12.40 & 11.31 & 7.924 & 13.64 \\
\hline
\end{tabular}

